\title{
Thermo-mechanical properties of Bundelkhand granite near Jhansi, India
}

\author{
B. Singh $\mathbb{D} \cdot$ P. G. Ranjith $\cdot$ D. Chandrasekharam $\cdot$ D. Viete $\cdot$ \\ H. K. Singh $\cdot$ A. Lashin $\cdot$ N. Al Arifi
}

Received: 17 March 2015/ Accepted: 28 May 2015/Published online: 30 June 2015

(C) Springer International Publishing Switzerland 2015

\begin{abstract}
Creation of optimal fracture networks through enhanced geothermal system within the reservoir for the extraction of the geothermal energy will require proper understanding of the thermo-mechanical behavior of the reservoir rocks i.e. granites. Current research work has focused the thermo-mechanical properties of granite under various temperature and strain rate conditions. Bundelkhand granite of India has been investigated for the proposed research work. Four different strain rates viz. $0.05,0.5,5.0$ and $50.0 \mathrm{~mm} /$ $\mathrm{min}$ at three different temperatures viz. room temperature $\left(25^{\circ} \mathrm{C}\right), 200$ and $400{ }^{\circ} \mathrm{C}$ were considered for experimental analysis. It was observed that at room temperature, with increasing strain rate the uniaxial compressive strength of the rock increases and the same
\end{abstract}

B. Singh $(\bowtie)$

IITB-Monash Research Academy, Indian Institute of Technology of Bombay, Mumbai 400076, India

e-mail: banambar.iitb@gmail.com

B. Singh - D. Chandrasekharam - H. K. Singh Department of Earth Sciences, Indian Institute of Technology of Bombay, Mumbai 400076, India

B. Singh · P. G. Ranjith · D. Viete

Civil Engineering Department, Monash University, Clayton, Melbourne 3800, Australia

A. Lashin

Geology Department, Faculty of Science, Benha

University, Benha 13518, Egypt trend is also observed at higher temperature conditions. However, at low strain rate $(0.05 \mathrm{~mm} / \mathrm{min})$ the compressive strength decreases with increase in temperature and the trend is irregular at higher strain rates. It was also observed that Young's modulus of Bundelkhand granite increases with increase in strain rate however it reduces with increase in temperature. Thermal conductivity value of Bundelkhand granite ranges from 3.1 to $3.6 \mathrm{~W} / \mathrm{m} \mathrm{K}$.

Keywords Bundelkhand granite - Thermomechanical properties - Thermal conductivity · Enhanced geothermal system

\footnotetext{
A. Lashin

Petroleum and Natural Gas Engineering Department, College of Engineering, King Saud University, Riyadh 11421, Saudi Arabia

A. Lashin

Geothermal Resources Engineering Group, Sustainable Energy Technologies Centre, King Saud University, Riyadh 11451, Saudi Arabia

N. Al Arifi

Geology and Geophysics Department, College of Science, King Saud University, Riyadh 11451, Saudi Arabia
} 


\section{Introduction}

The Bundelkhand craton is of Archeo-Proterozoic age and comprises the Central Indian Shield in association with the Aravali and the Singhbhum cratons. The Bundelkhand massifs are situated in the central part of the Indian peninsula which outcrops in a semicircular shape. These massifs are bounded by Son-Normada lineament on south, the Great Boundary fault of Aravalli in the west and the Himalayas in the north. The most predominated rocks in the region are the several generations of granitic rocks ranging in age from late Archean to early Proterozoic. $\mathrm{Rb}-\mathrm{Sr}$ dating of these rocks indicates an average age of $2550 \mathrm{Ma}$ (Sarkar et al. 1985). The tonalite-trondhjemite-granodiorite (TTG) gneisses, reported from the Bundelkhand granite complex, record the oldest partial and metamorphic melting event in this region i.e. $\sim 3.3 \mathrm{Ga}$ (Mondal et al. 2002).

Bundelkhand granites are very widely distributed in central part of India. These granites contain significant concentration of radioactive elements providing a reasonable heat flow value to these granites. Therefore these granites can be considered as a potential Hot Dry Rock resource. On the other hand these granites have very low porosity and primary permeability. In order to increase the fluid flow within the reservoir, artificial fracture networks are required to be developed inside the reservoir. To develop an artificial fracture network within the low permeable reservoir requires a complete knowledge of the mechanical properties of the granites. The mechanical properties of rocks depend upon different physical parameters like mineralogy, structure, temperature and stress. In addition to this, a proper understanding of the thermo-mechanical (TM) behavior of the granites is also essential as high temperature affects the strength of rocks. In practice, the geothermal reservoirs at depth are under high temperature and pressure condition and the rocks behave dynamically as a function of temperature and pressure. So the development of fracture networks within a complex dynamic environment requires knowledge of the TM behavior of these rocks.

Worldwide since 1970s, many of the countries which have reservoirs that are noncommercial for conventional hydrothermal reservoirs viz. Fenton hill of United States, Rosmanowes of United kingdom,
Soultz of France and Cooper basin of Australia etc. are focusing on developing techniques for the creation of geothermal reservoirs through artificial fracture network.

This paper focuses on the critical analysis of the TM properties of Bundelkhand granites of India.

\section{Literature review}

\subsection{Geology}

The Bundelkhand craton is one of the four Archean shields in India (Fig. 1). The Bundelkhand shield occupies nearly $29,000 \mathrm{~km}^{2}$ in the Central Indian Shield region. It consists of supracrustal gneisses with or without TTG affinity, metapelites, amphibolites, iron rich and less abundantly, manganese-rich metasedimentary rocks, marble, calc-silicate rocks and quartzites. Several phases of compositionally different felsic intrusive rocks, felsic volcanic rocks, giant quartz veins (GQVs) (Pati et al. 2007), and mafic-ultramafic intrusive rocks (Basu 1986; Mondal et al. 2002; Malviya et al. 2006) are also present. The GQVs are up to $70 \mathrm{~m}$ wide and can exceed $100 \mathrm{~km}$ in strike length, and are the most conspicuous regional structures observed as curvilinear features throughout the Bundelkhand craton. These veins were later intruded by NW trending mafic dikes. The supracrustal gneisses show three phases of folding and the imprint of a crustal-scale brittle ductile shearing ( $\sim \mathrm{E}-\mathrm{W}$ trending) episode that affected all major lithology except the mafic dikes (Pati et al. 2007; Malviya et al. 2006). The Bundelkhand rocks, in general, are metamorphosed to amphibolite facies (Basu 1986) and, in places, possibly to granulite facies. The entire region is at low altitude and slopes from south to north. All its important rivers flow in that direction.

The Bundelkhand granite hosts geothermal circulation at Tattapani (Minissale et al. 2000) and the reported heat generating capacity of these granites varies from 3-8 $\mu \mathrm{W} / \mathrm{m}^{3}$ (Chandrasekharam and Chandrasekhar 2008). These are fertile granites with high thorium (3-101 ppm), uranium (5-14 ppm) and potassium contents, indicating that they are high heat generating granites (Chandrasekharam and Chandrasekhar 2010). These are high heat producing granites and the heat generation ranges from 1.4 to $5.4 \mu \mathrm{W} / \mathrm{m}^{3}$ (Singh et al. 2015). 


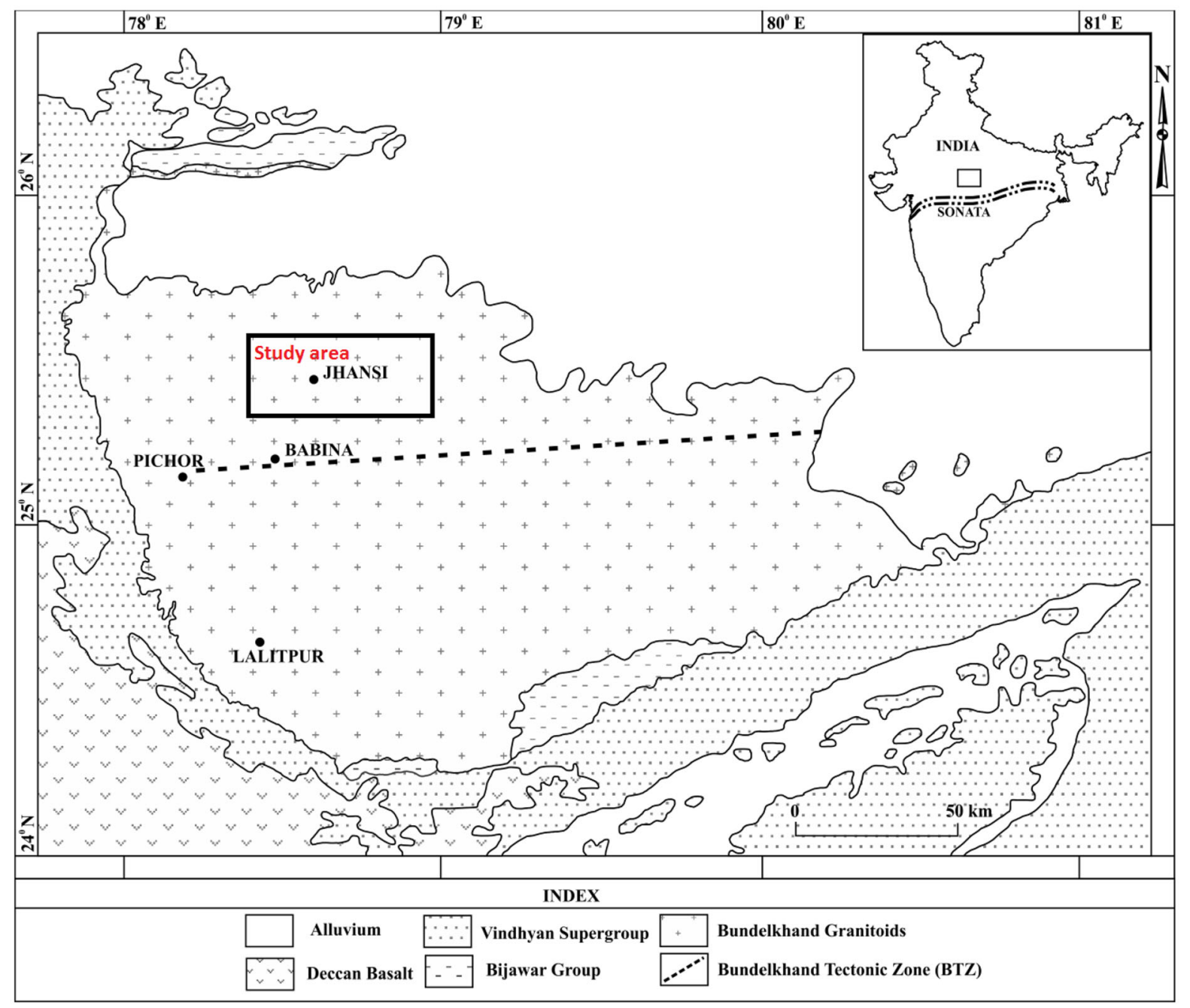

Fig. 1 Geological map of Bundelkhand Craton (modified after Pati et al. 2007)

\subsection{Thermo-mechanical study}

Extensive work has been carried out by many of the authors to measure the mechanical properties of granite using different standardized methods. Katz et al. (2000) and Vasconcelos et al. (2007) have measured the mechanical properties of rock using Schmidt Hammer method. They used ultrasonic pulse velocity and hardness number for the evaluation of the elastic and strength measurement of rocks. However, very limited studies have been carried out focusing the effect of temperature on the mechanical properties of the granites.

Since last few decades, the study of the effect of temperature on the physical and mechanical properties of rocks has been studied by earlier researchers. Heuze (1983) studied different mechanical properties like deformation modulus, Poisson's ratio, tensile strength, compressive strength, cohesion and internal friction angle, viscosity, and other parameters and discussed the dependence of lateral pressure and high temperature on thermal expansions of different granites. But they didn't consider the effect of strain rate on the mechanical properties of granites.

However, most of the previous works studied the mechanical properties of rocks at room temperature after they have attained to a specified temperature. In general, cooling down of a specimen to room temperature after heating to a specified high temperature will 
result in the formation of abundant thermal microcracks. Therefore the results of the above mentioned experiments are not sufficient to reflect the essential characteristics of rocks at higher temperature.

Many scholars have also studied the physical and mechanical properties of rocks under high temperature. However, the behavior of rocks is very complex under TM coupling as most mechanical parameters such as compressive strength and elastic modulus show drastic difference as compared with those at room temperature (Hudson et al. 2005). Study on micro-scale by Zuo (2006) has shown that the strength of sandstone with an initial increment decreases with the increase in temperature within a certain interval. Similarly, Xu and Liu (2000) have shown that the strength decreases with the increase in temperature for most of the rocks, and this downward trend depends on the rock type. Furthermore, former studies on the TM properties of rocks have not considered the characterization of crack growth during the TM study of the rock. The mechanical behaviour of rock has been analysed by varoius researchers using an acoustic measurement method (Ranjith et al. 2008; Wasantha et al. 2013). They differentiated the stable crack growth zone and rock failure zone of different rock specimen using the acoustic emission counts.

Zhang et al. (2009) studied the mechanical properties of marble, limestone and sandstone at high temperature using MTS810 hydraulic servo system and MTS 653.02 high temperature furnace. From the stress-strain curve, they observed that the rocks have compression phase and elastic stages at normal temperature to $800{ }^{\circ} \mathrm{C}$ and with the increase of temperature plasticity increases. Peak strength study (Fig. 2) shows a downtrend from normal to $200{ }^{\circ} \mathrm{C}$, a little fluctuation between 200 and $600^{\circ} \mathrm{C}$ and a sharp decrease at more than $600{ }^{\circ} \mathrm{C}$. Similarly, the peak strain of sandstone, marble and limestone rapidly increases after 600,200 and $200{ }^{\circ} \mathrm{C}$ temperature respectively. Elastic modulus of the rocks also decreases with increase in temperature.

Dwivedi et al. (2008) measured the TM properties of granites of India and other places where he used the core samples in UTM machine to observe the effect on rock strength at different temperature interval. They observed that with an initial decrease, the compressive strength of the granites (Fig. 3) increases with increase in temperature whereas tensile strength gradually decreases with increase in temperature. Similarly, as

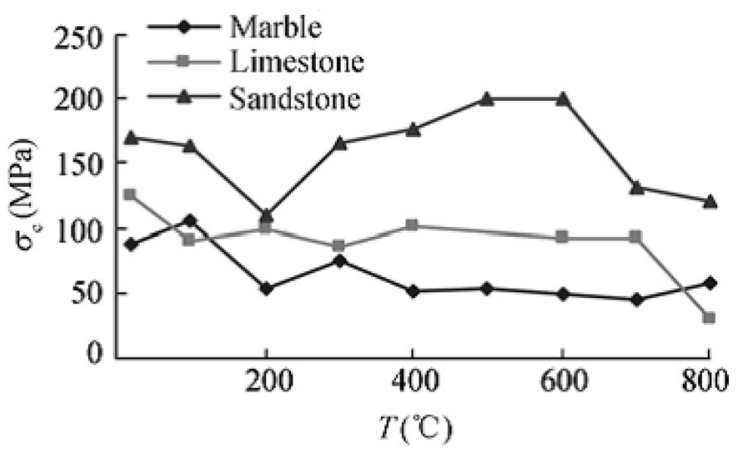

Fig. 2 Variation of peak strength with temperature, Zhang et al. (2009)

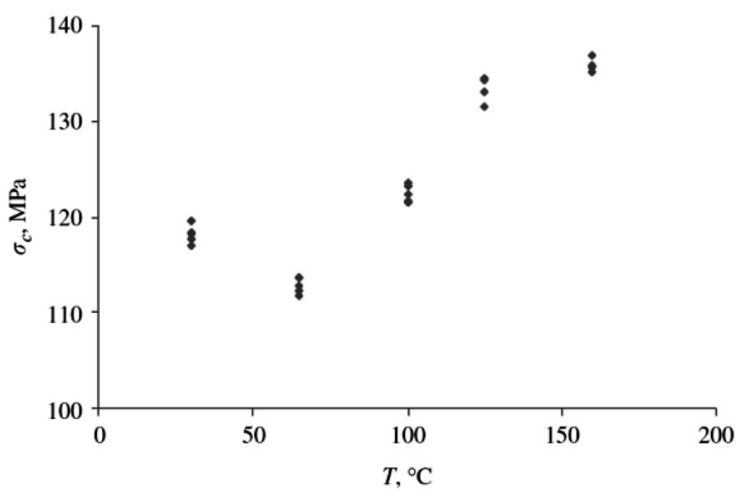

Fig. 3 Plot of compressive strength (sc) versus temperature for Indian granite (Dwivedi et al. 2008)

temperature rises young's modulus also increases with an initial decrease as temperature rises. They also found that there is a reduction in width of the preexisting micro-cracks with increase in temperature. Zhao (1994) studied the TM properties of Carnmenellis granite and observed that by increasing the temperature from 20 to $200{ }^{\circ} \mathrm{C}$, uniaxial compressive strength of the specimen can be reduces to $40 \%$.

From the literature review, it is appeared that though a significant amount of effort has been made by earlier authors on the study of the mechanical properties of different kinds of rock, but study on the TM properties of rocks is limited. Singh et al. (2013) studied TM properties of Harcourt granite, Australia. Various authors have worked on mechanical properties of various granites of India; however, limited work has been carried out on the TM properties of the Indian granites. This investigation is focused on the study of the TM properties of Bundelkhand granite in a stable 
temperature environment at different temperature and strain rate conditions.

\section{Methodology}

\subsection{Geology}

Bundelkhand granite from Jhansi district, Uttar Pradesh, India is investigated for the current research work. Geology of the study area is studied in order to understand the field conditions like rock type, mineralogy and stress pattern etc. The study area is situated at Jhansi district of Uttar Pradesh, India. It covers the granitic exposures of Jhansi city and its surrounding areas like Deilly, Goramachia, Khialar, Pratappura.

Big boulder samples of Bundelkhand granite were collected from the field area of Jhansi and were transported to the department of Earth sciences, IIT Bombay.

Core samples of $44 \mathrm{~mm}$ diameter to $88 \mathrm{~mm}$ length were prepared and then transported to Monash University for study of TM properties of the rock. Both ends of the samples were grinded and polished in order to make both ends perpendicular to the axis of the sample. Sample preparation and uniaxial compressive strength test experiments were carried out at Civil engineering department of Monash University, Melbourne, Australia.

\subsection{Thermo-mechanical study}

Thermo-mechanical investigation delineates the mechanical properties of rock under different temperature and strain rate condition. "ASTM D7012-10 Standard Test Method for measurement of Compressive Strength and Elastic Modulus of Intact Rock Core Specimens under varying states of Strain and Temperatures" has been followed for the current experimental work. The experimental set up for the TM study is shown in Fig. 4.

The compressive strength tests were carried out at four different stain rates, i.e. $0.05,0.5,5.0$ and $50 \mathrm{~mm} / \mathrm{min}$ along with three different temperature intervals i.e. at room temperature $\left(25^{\circ} \mathrm{C}\right), 200$ and $400{ }^{\circ} \mathrm{C}$. From preliminary compressive strength study, it was observed that the strain rate of $0.5 \mathrm{~mm} / \mathrm{min}$ took 5-7 $\mathrm{min}$ to failure and therefore considered as the standard strain rate for
Bundelkhand granites. Whereas, strain rate of $0.05 \mathrm{~mm} /$ min required an average of $45 \mathrm{~min}, 5.0 \mathrm{~mm} / \mathrm{min}$ required an average of $30-40 \mathrm{~s}$ and $50.0 \mathrm{~mm} / \mathrm{min}$ required an average of 8-10 s and therefore considered as low strain rate, high strain rate and very high strain rate respectively for the current experimental work.

Compressive strength tests were carried out on the Baldwin $500 \mathrm{kN}$ testing machine. The Baldwin $500 \mathrm{kN}$ machine is a sophisticated compressive strength testing machine which can apply load up to $500 \mathrm{kN}$ and can perform high speed data acquisition and high resolution signal conditioner.

Instiron Oven $600{ }^{\circ} \mathrm{C}$ was used for the heating of the rock sample which can heat up to maximum of $600{ }^{\circ} \mathrm{C}$. It was observed that after the heating process of the specimen there is a heat loss of $100{ }^{\circ} \mathrm{C}$ over 5 min time period while transporting the specimen from oven to the Baldwin machine. Therefore, oven was set up within the Baldwin machine itself so that heat loss due to transportation can be stopped. Again simultaneous heating of specimen while the experiment is in progress gives an advantage of carrying out the experiment at the specified temperature.

Samples were heated at a rate of $5^{\circ} \mathrm{C} / \mathrm{min}$ for the test at $200{ }^{\circ} \mathrm{C}$ and at a rate of $10{ }^{\circ} \mathrm{C} / \mathrm{min}$ for the test at $400{ }^{\circ} \mathrm{C}$ which then kept on hold for an hour at the specified temperature so as to provide enough time to the granite sample to achieve desired temperature at the core and at its surface. A thermocouple was put inside the oven which was attached to surface of the specimen so that the temperature of the specimen can be measured while the experiment is in progress. Three samples for each test were used for the experimental work.

Radial strain was measured using the MTS Laser Extensometer. Two reflecting stickers were put on the cylindrical surface of the rock specimen parallel to each other and to the axis of the specimen and the change in displacement were measured using the laser extensometer. Axial strain was measured from the displacement of the plates of the Baldwin machine for which a compliance test for specific sample size was also carried out.

In addition, acoustic emission measuring instrument was used for the study of fracture mechanics. Acoustic emission is a phenomenon of generating elastic waves which is a result of a small surface displacement of a material produced due to stress 


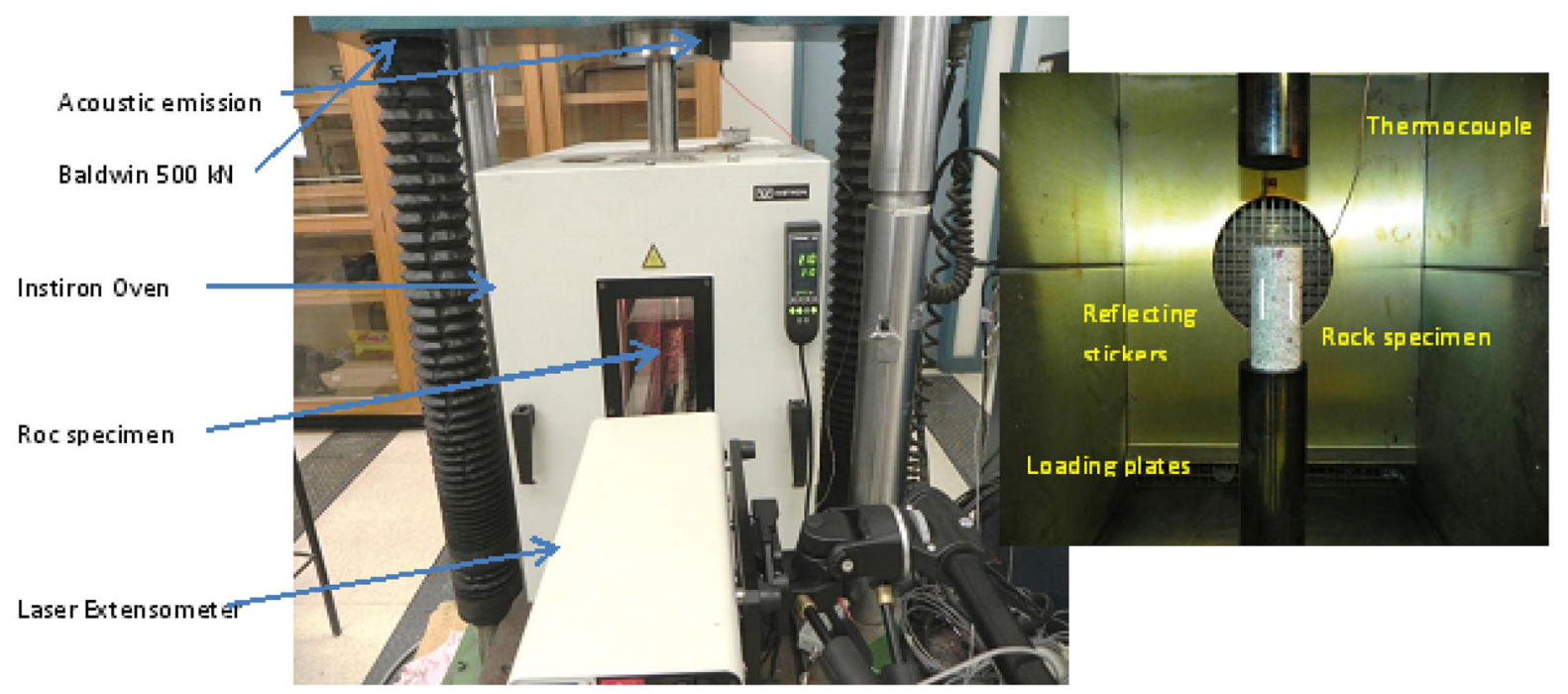

Fig. 4 Photograph showing experimental setup for thermo-mechanical study

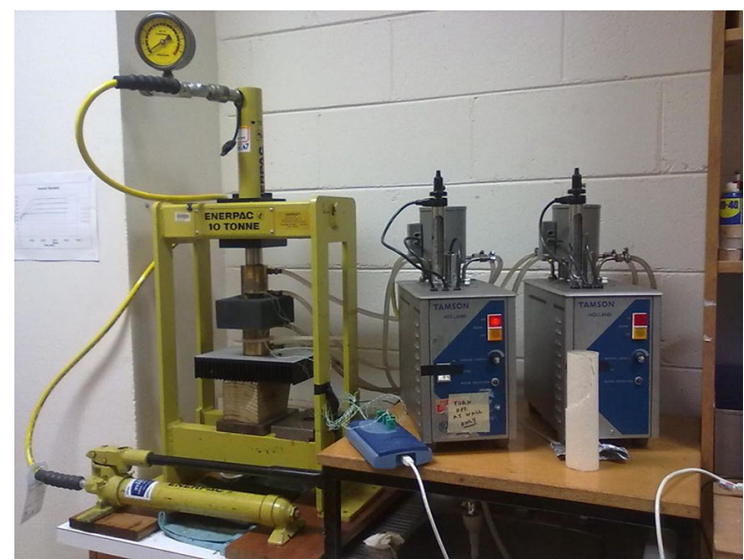

Fig. 5 Divided bar instrument for thermal conductivity measurement

waves generated when the energy in a material or on its surface is released rapidly. Thus, it can be useful for the study of crack initiation and its failure within a specimen.

\subsection{Thermal conductivity}

Thermal conductivity $(\mathrm{k})$ is defined as the quantity of heat (Q) transmitted through a unit thickness (L) in a direction normal to a surface of unit area (A) due to a unit temperature gradient $(\Delta \mathrm{T})$ under steady state conditions when the heat transfer is dependent only on the temperature gradient. Equation form this becomes the following:
$k=Q \times L /(A \times \Delta T)$

Thermal conductivity was measured at geoscience department of Monash University of Australia using the Divided bar method (Fig. 5). Divided Bar method is one of the most common methods for measuring thermal conductivity of consolidated rock samples. A sample of unknown conductivity is placed between two samples of known conductivity (usually brass plates). The setup is usually vertical with the hot brass plate at the top, the sample in between and then the cold brass plate at the bottom. Heat is supplied at the top and made to move downwards to stop any convection within the sample. Measurements are taken after the sample has reached to the steady state (with zero heat gradient or constant heat over entire sample) The sample of $25 \mathrm{~mm}$ diameter and $20 \mathrm{~mm}$ thickness were used for the experiments.

\section{Results and discussion}

\subsection{Thermo-mechanical study}

\subsubsection{Bundelkhand granite: alkali granites}

Results of Uniaxial compressive strength test at standard strain rate $(0.5 \mathrm{~mm} / \mathrm{min})$ and room temperature $\left(25^{\circ} \mathrm{C}\right)$ is shown in Fig. 6 which shows variation of axial strain and radial strain against stress. The peak 
load was $323 \mathrm{kN}$ and the peak strength was 210.6 MPa with radial strain of 0.011 and axial strain 0.023 . From the axial strain plot it was observed that, after an initial adjustment between the loading plates and both ends of the sample, the plot is linear up to the failure load which signifies of an elastic zone. After the failure load the stress value suddenly drops to zero which indicates about an elastic-brittle failure with the absence of plastic zone.

Radial strain and acoustic emission (AE) data is plotted against compressive stress value in Fig. 7. Based on the AE counts the time period is classified into crack closure, stable crack growth zone and unstable crack growth zone. It was observed that stable cracks forms between approximately 170-200 MPa of stress and unstable crack growth occurs thereafter. Maximum number of $\mathrm{AE}$ hits recorded during the failure of the rock sample.

Stress-strain curve of compressive strength test at room temperature $\left(25^{\circ} \mathrm{C}\right)$ and $0.05 \mathrm{~mm} / \mathrm{min}$ strain is shown in Fig. 8. The failure of the rock specimen occurred after $77 \mathrm{~min}$. The peak load was $311 \mathrm{kN}$ and the peak strength was $202 \mathrm{MPa}$ with an axial strain of 0.018. Stress-strain curve shows an elastic-brittle failure of the rock specimen at room temperature and $0.05 \mathrm{~mm} / \mathrm{min}$ strain rate.

Similarly, the plot of AE data with strain against stress in Fig. 9 shows crack closure zone up to $120 \mathrm{MPa}$ stress followed by crack growth and propagation resulting in failure of the rock specimen.

Result of Compressive strength test carried at room temperature at strain rate of $5.0 \mathrm{~mm} / \mathrm{min}$ is shown in Fig. 10. The failure of the rock specimen occurred in $<30$ s. The peak load was $358 \mathrm{kN}$ and the peak strength was $232 \mathrm{MPa}$ with Radial strain of 0.0013 and axial strain 0.034 . The axial strain plotted against compressive strength shows an elastic-brittle failure.

Similarly, plot of AE data with axial strain against stress in Fig. 11 shows crack closure zone up to $70 \mathrm{MPa}$ stress followed by crack growth and propagation resulting in failure of the rock specimen.

Rock specimen of Bundelkhand alkali granite was tested at $50 \mathrm{~mm} / \mathrm{min}$ strain rate at room temperature $\left(25^{\circ} \mathrm{C}\right)$. Figure 12 shows the results of stress and $\mathrm{AE}$ counts against axial strain at room temperature. Failure of the specimen occurred in $5.51 \mathrm{~s}$. The peak load for the failure of the specimen was $523.5 \mathrm{kN}$ and the compressive strength is $334.5 \mathrm{MPa}$ with the axial strain of 0.039 . Based on the AE counts in the graph it is observed that formation of stable cracks starts from approximately $150 \mathrm{MPa}$ stress and continues to $300 \mathrm{MPa}$ of stress. Unstable crack growth occurs thereafter until the failure of the specimen.

Figure 13 shows stress-strain curve of the specimen for $200{ }^{\circ} \mathrm{C}$ test at $0.5 \mathrm{~mm} / \mathrm{min}$ strain rate. Failure of the rock specimen during the compressive strength test occurred under $7 \mathrm{~min}$. The peak load was $324 \mathrm{kN}$ and the peak strength was $209 \mathrm{MPa}$ with radial strain of 0.0002 and axial strain $0.035 \mathrm{~mm}$. It was observed that even at $200{ }^{\circ} \mathrm{C}$ there was no plastic deformation occurred indicating an elastic-brittle failure of the specimen. The acoustic emission counts (Fig. 14) indicate that stable crack growth occurred after $50 \mathrm{MPa}$ followed by unstable crack growth process after $200 \mathrm{MPa}$.

The stress strain curve of the compressive strength test at $400{ }^{\circ} \mathrm{C}$ and 0.5 strain rate is shown in Fig. 15 . Failure of the rock specimen during the compressive
Fig. 6 Graph showing trend of axial strain and radial strain plotted against stress tested at room temperature $\left(25^{\circ} \mathrm{C}\right)$ and $0.5 \mathrm{~mm} / \mathrm{min}$ strain rate

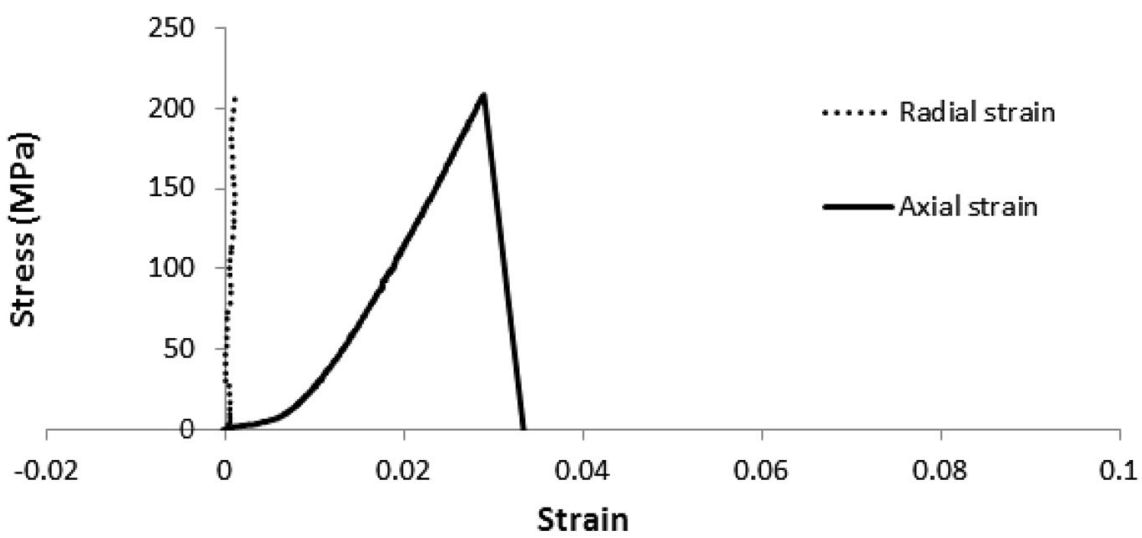


Fig. 7 Graph showing plot of the radial strain and the acoustic emission counts against the stress for the compressive strength test at room temperature $\left(25^{\circ} \mathrm{C}\right)$ and $0.5 \mathrm{~mm} / \mathrm{min}$ strain rate

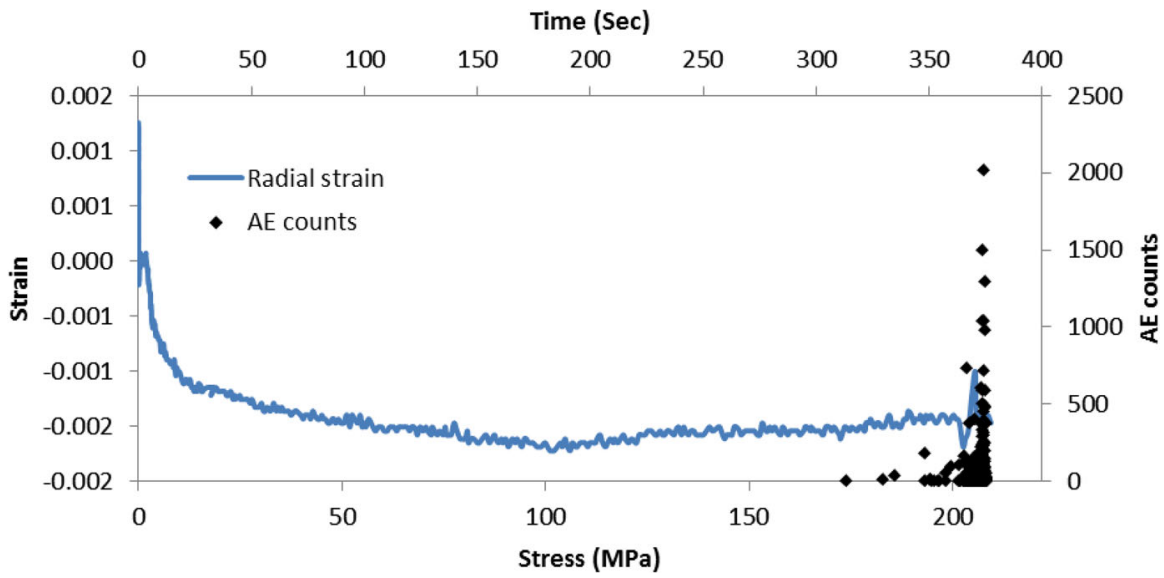

Fig. 8 Graph showing trend of axial strain and radial strain plotted against stress tested at room temperature $\left(25^{\circ} \mathrm{C}\right)$ and $0.05 \mathrm{~mm} / \mathrm{min}$ strain rate

Fig. 9 Graph showing plot of the radial strain and the acoustic emission counts against the stress for the compressive strength test at room temperature $\left(25^{\circ} \mathrm{C}\right)$ and $0.05 \mathrm{~mm} / \mathrm{min}$ strain rate
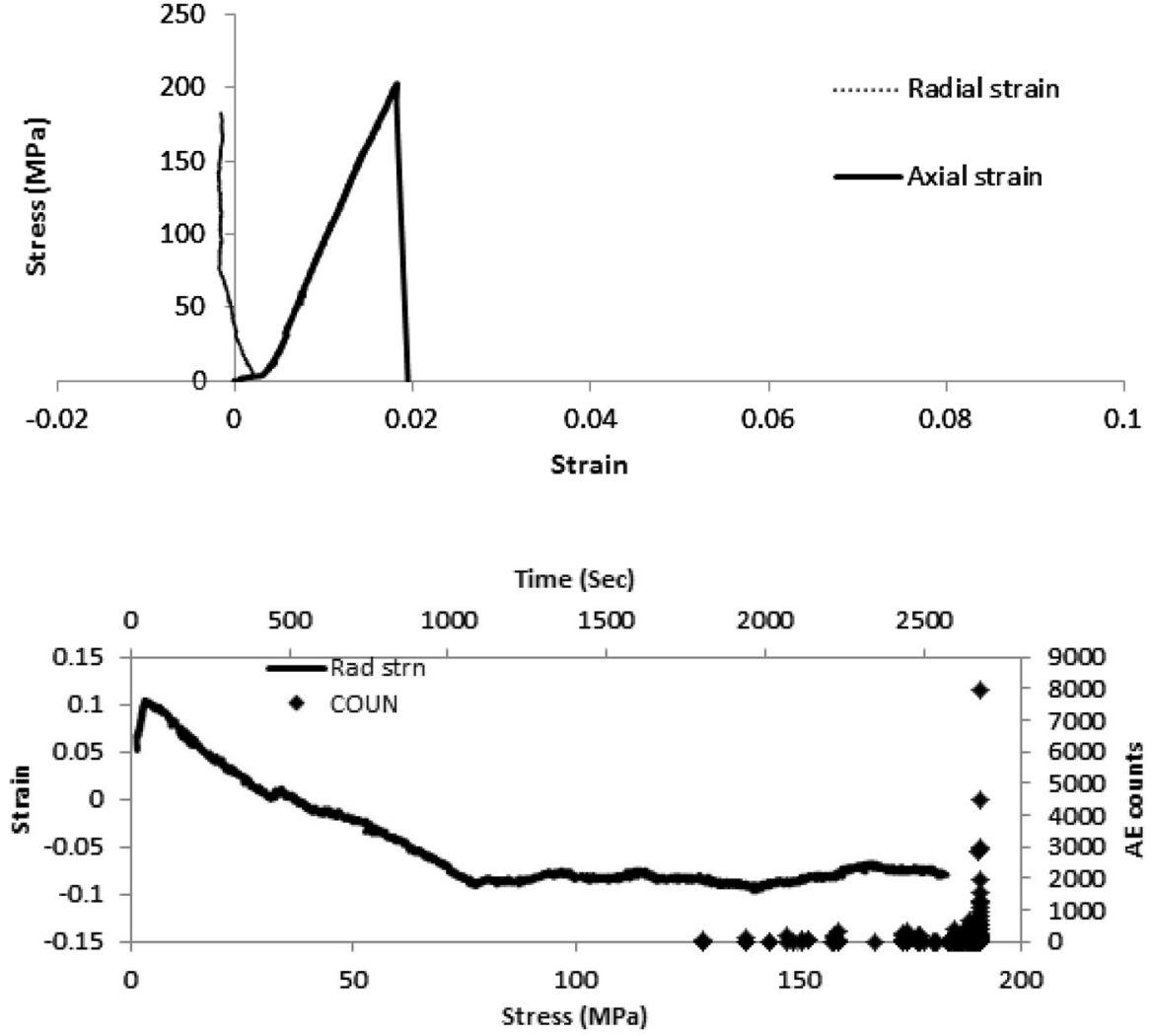

strength test occurred within $5 \mathrm{~min}$. The peak load was $212 \mathrm{kN}$ and the peak strength was $136 \mathrm{MPa}$ with radial strain of 0.002 and axial strain 0.021 . It was observed that even at $400{ }^{\circ} \mathrm{C}$ there is no plastic deformation occurred indicating an elastic-brittle failure of the specimen. Acoustic emission data indicates that stable crack growth occurred after
$40 \mathrm{MPa}$ stress followed by unstable crack growth after $95 \mathrm{MPa}$ stress (Fig. 16).

From stress-strain curves for different temperatures and strain rates, it is observed that at specific temperature the axial strain at failure increases with increase in strain rate. Similarly, at specific strain rate the axial strain at failure increases from room 
Fig. 10 Graph showing trend of axial strain and radial strain plotted against stress tested at room temperature $\left(25{ }^{\circ} \mathrm{C}\right)$ and $5.0 \mathrm{~mm} / \mathrm{min}$ strain rate
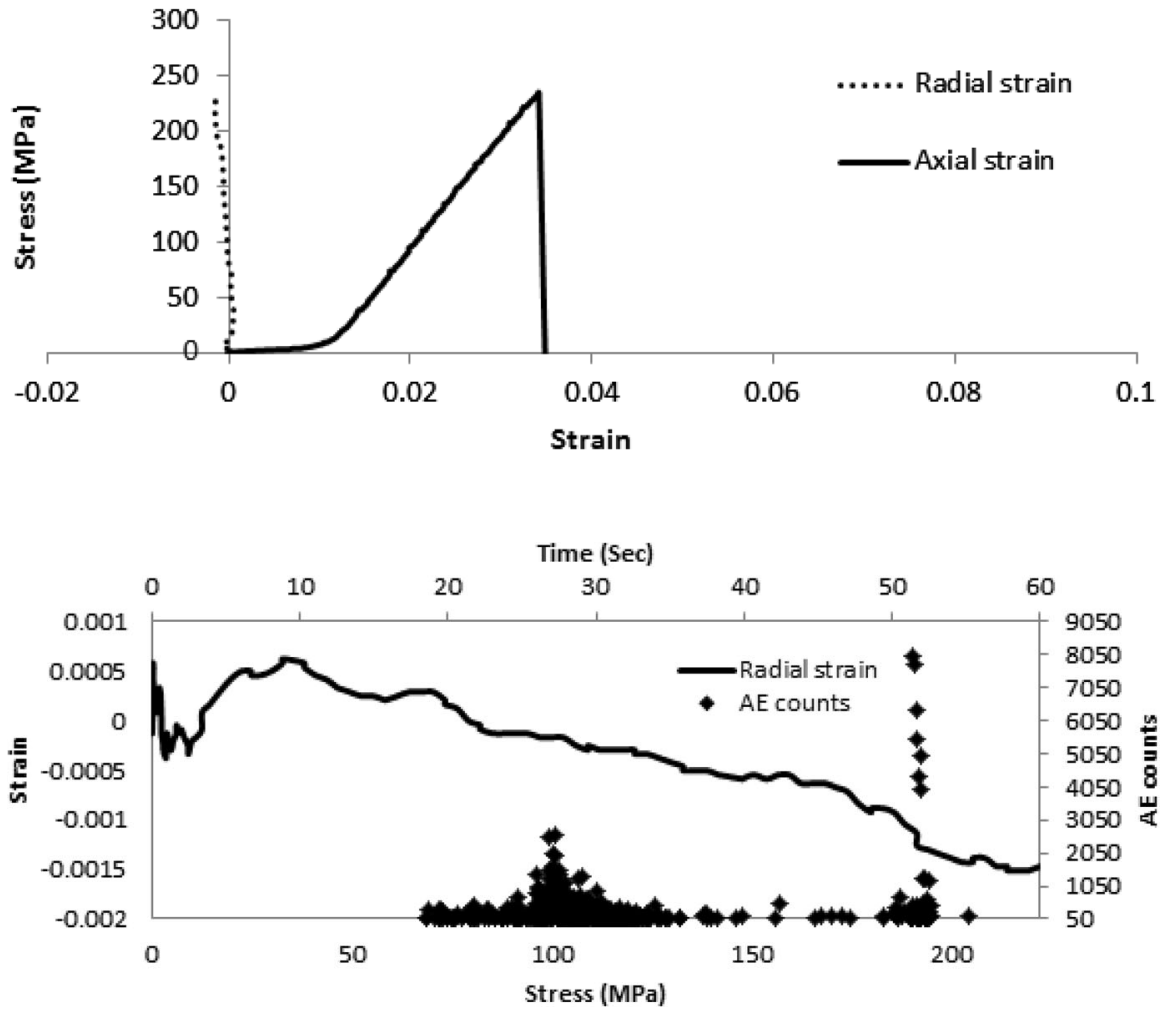

Fig. 11 Graph showing plot of the radial strain and the acoustic emission counts against the stress for the compressive strength test at room temperature $\left(25^{\circ} \mathrm{C}\right)$ and $5.0 \mathrm{~mm} / \mathrm{min}$ strain rate

Fig. 12 Graph showing plot of stress and AE counts against axial strain at room temperature $\left(25^{\circ} \mathrm{C}\right)$ and $5.0 \mathrm{~mm} / \mathrm{min}$ strain rate

Fig. 13 Graph showing trend of axial strain and radial strain plotted against stress tested at $200{ }^{\circ} \mathrm{C}$ and $0.5 \mathrm{~mm} / \mathrm{min}$ strain rate
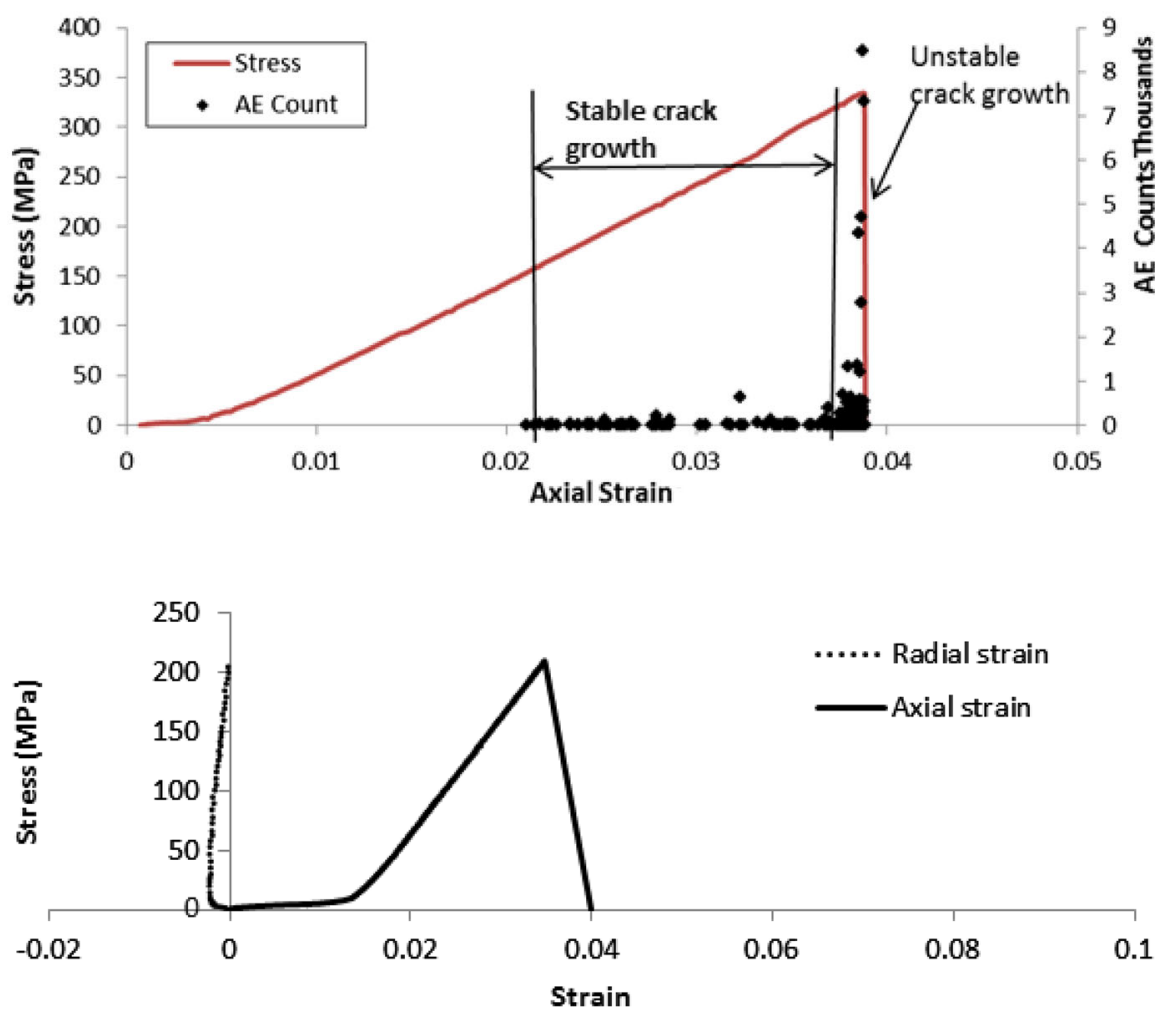
Fig. 14 Graph showing plot of the radial strain and the acoustic emission counts against the stress for the compressive strength test at $200{ }^{\circ} \mathrm{C}$ and $0.5 \mathrm{~mm} / \mathrm{min}$ strain rate
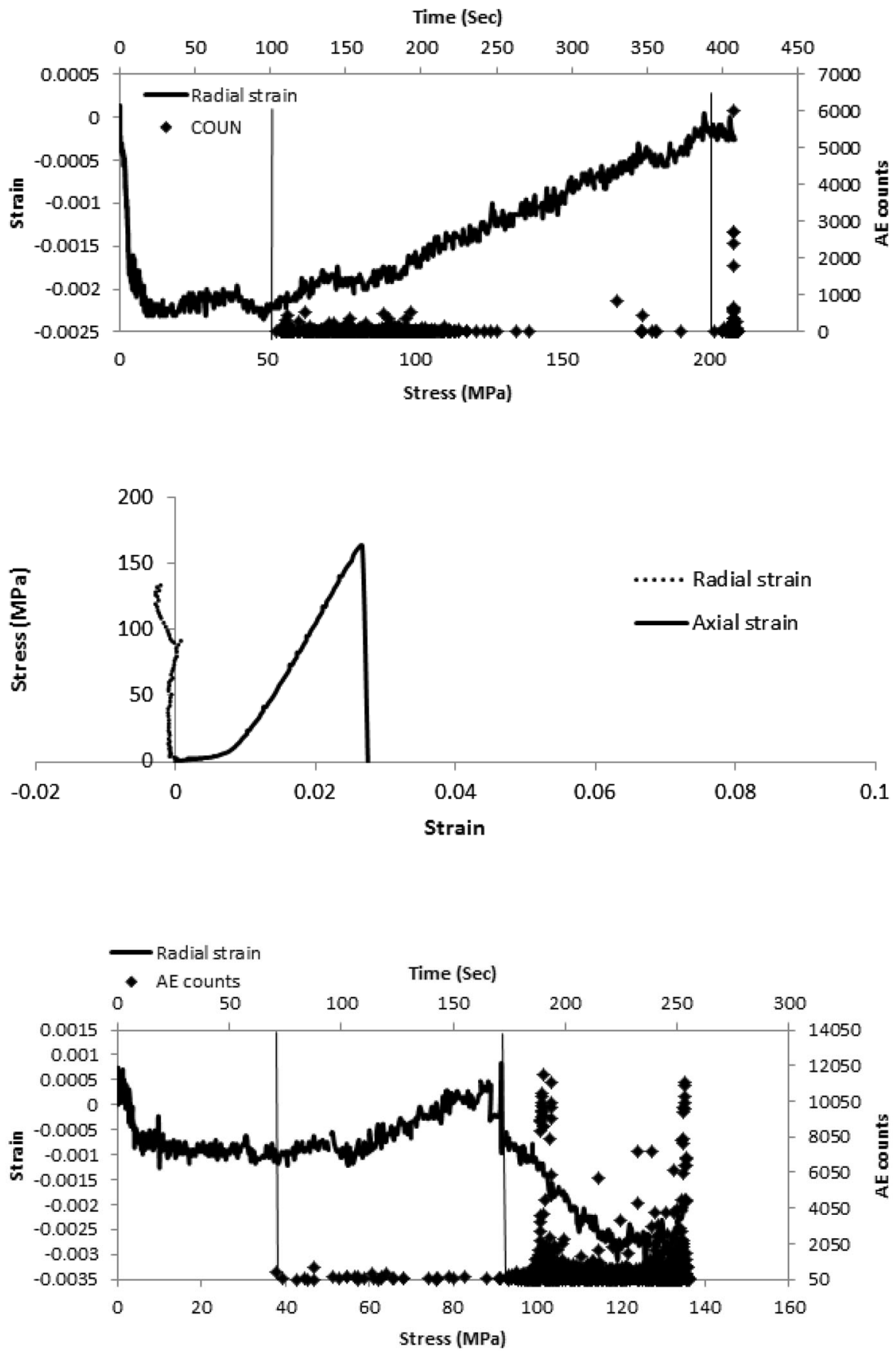

Fig. 16 Graph showing plot of the radial strain and the acoustic emission counts against the stress for the compressive strength test at $400{ }^{\circ} \mathrm{C}$ and $0.5 \mathrm{~mm} / \mathrm{min}$ strain rate
Fig. 15 Graph showing trend of axial strain and radial strain plotted against stress tested at $400{ }^{\circ} \mathrm{C}$ and $0.5 \mathrm{~mm} / \mathrm{min}$ strain rate 
Table 1 Thermo mechanical properties of alkali granite of Bundelkhand granite at different temperature and strain rate conditions

\begin{tabular}{|c|c|c|c|c|c|c|c|c|c|}
\hline \multirow{3}{*}{$\begin{array}{l}\text { Strain rate } \\
(\mathrm{mm} / \mathrm{min})\end{array}$} & \multicolumn{9}{|c|}{ Temperature } \\
\hline & \multicolumn{3}{|l|}{$25^{\circ} \mathrm{C}$} & \multicolumn{3}{|l|}{$200{ }^{\circ} \mathrm{C}$} & \multicolumn{3}{|l|}{$400{ }^{\circ} \mathrm{C}$} \\
\hline & $\begin{array}{l}\mathrm{UCS} \\
(\mathrm{MPa})\end{array}$ & $\begin{array}{l}\text { Axial } \\
\text { strain }\end{array}$ & $\begin{array}{l}\text { Y's modulus } \\
\text { (Gpa) }\end{array}$ & $\begin{array}{l}\mathrm{UCS} \\
(\mathrm{MPa})\end{array}$ & $\begin{array}{l}\text { Axial } \\
\text { strain }\end{array}$ & $\begin{array}{l}\text { Y's modulus } \\
\text { (Gpa) }\end{array}$ & $\begin{array}{l}\text { UCS } \\
(\mathrm{MPa})\end{array}$ & $\begin{array}{l}\text { Axial } \\
\text { strain }\end{array}$ & $\begin{array}{l}\text { Y's modulus } \\
\text { (Gpa) }\end{array}$ \\
\hline 0.05 & 203.0 & 0.0042 & 48.5 & 190.2 & 0.0044 & 42.8 & 153.1 & 0.0047 & 32.8 \\
\hline 0.5 & 223.8 & 0.0039 & 57.4 & 209.3 & 0.0041 & 50.6 & 160.0 & 0.0042 & 37.8 \\
\hline 5.0 & 232.5 & 0.0038 & 61.4 & 222.1 & 0.0037 & 60.1 & 174.6 & 0.0040 & 43.3 \\
\hline 50.0 & 334.6 & 0.0037 & 90.0 & 271.5 & 0.0037 & 73.0 & 203.0 & 0.0038 & 54.0 \\
\hline
\end{tabular}

Fig. 17 Average compressive strength of alkali granites for different strain rates at different temperature

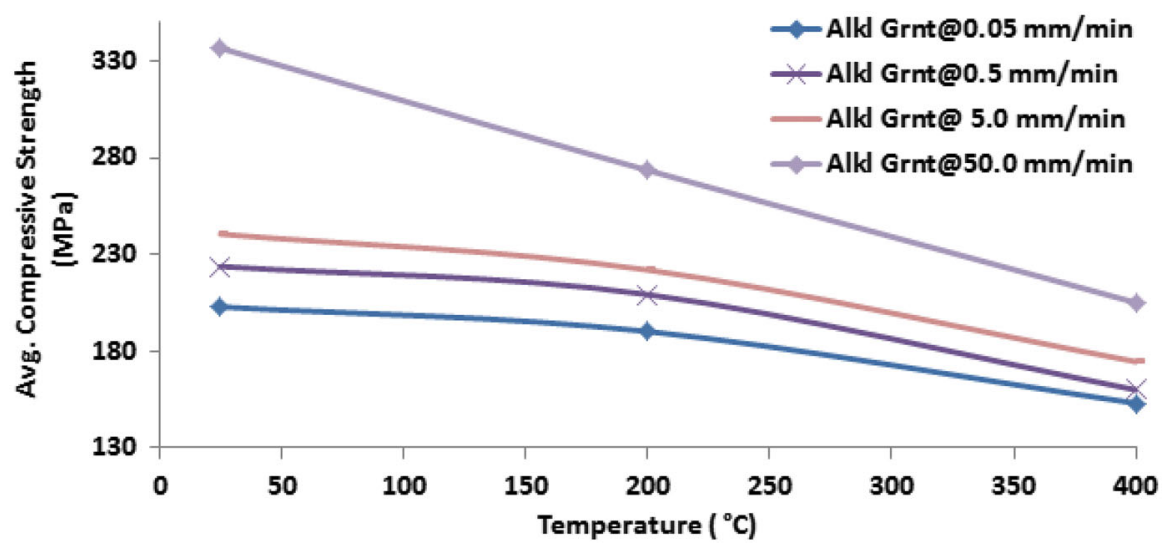

Fig. 18 Average compressive strength of alkali granites for different temperature at different strain rate

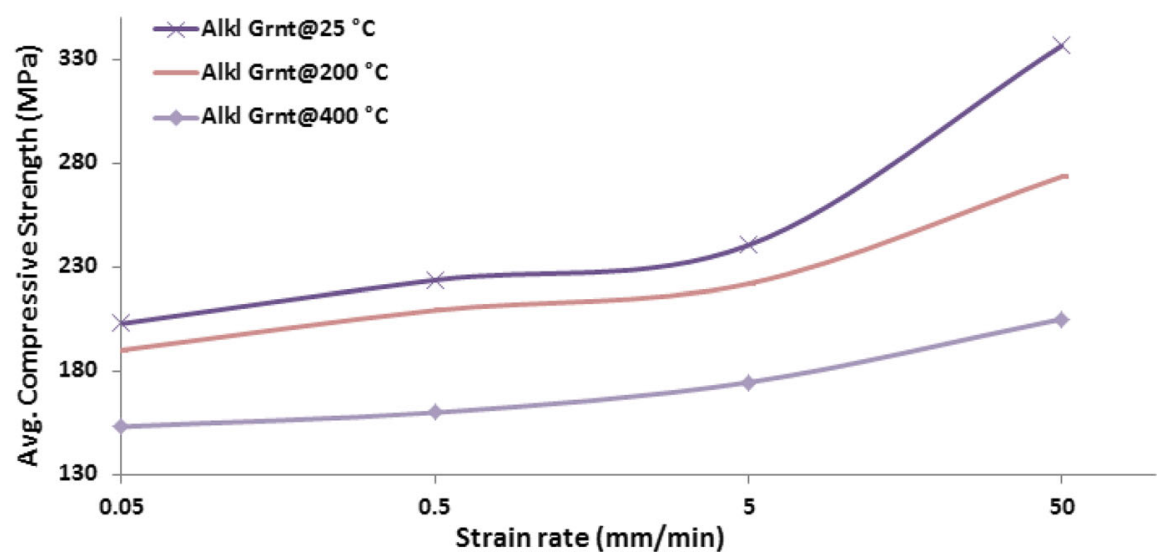

compressive strength at room temperature $\left(25^{\circ} \mathrm{C}\right)$ is 223.8 $\mathrm{MPa}$ which decreased to 209.3 $\mathrm{MPa}$ at $200{ }^{\circ} \mathrm{C}$ i.e. by $6 \%$, and it further decreased to $160 \mathrm{MPa}$ at $400{ }^{\circ} \mathrm{C}$ i.e. by $24 \%$. At strain rate of $5.0 \mathrm{~mm} / \mathrm{min}$, the compressive strength of the rock at room temperature $\left(25^{\circ} \mathrm{C}\right.$ ) is $232.5 \mathrm{MPa}$ which decreased to $222 \mathrm{MPa}$ at
$200{ }^{\circ} \mathrm{C}$ i.e. by $5 \%$ and further decreased to $174.6 \mathrm{MPa}$ i.e. by $21 \%$. At strain rate of $50.0 \mathrm{~mm} / \mathrm{min}$, the compressive strength of the rock at room temperature $\left(25^{\circ} \mathrm{C}\right)$ is $334.6 \mathrm{MPa}$ which decreased to $271.5 \mathrm{MPa}$ at $200{ }^{\circ} \mathrm{C}$ i.e. by $20 \%$ and further decreased to $203 \mathrm{MPa}$ i.e. by $25 \%$. This suggests that the uniaxial 
compressive strength of alkali granite reduces insignificantly from room temperature $\left(25^{\circ} \mathrm{C}\right)$ to $200{ }^{\circ} \mathrm{C}$ whereas it reduces very rapidly with further increase in temperature.

Similarly, at room temperature $\left(25^{\circ} \mathrm{C}\right)$, with increasing strain rate the compressive strength of the rock increases (Fig. 18). At $0.05 \mathrm{~mm} / \mathrm{min}$ strain rate, the compressive strength is $203 \mathrm{MPa}$ which increased to $223.8 \mathrm{MPa}$ at $0.5 \mathrm{~mm} / \mathrm{min}$ i.e. by $10 \%$, but the increase in strength is very less from 0.5 to $5.0 \mathrm{~mm} / \mathrm{min}$ which is $232.5 \mathrm{MPa}$ i.e. by $4 \%$. However, compressive strength observed at $50 \mathrm{~mm} / \mathrm{min}$ is 334.6 i.e. increased by $44 \%$. Similarly, At $200{ }^{\circ} \mathrm{C}$, the compressive strength at $0.05 \mathrm{~mm} / \mathrm{min}$ strain rate is $190.2 \mathrm{MPa}$ which increases to $209.3 \mathrm{MPa}$ at $0.5 \mathrm{~mm} / \mathrm{min}$ strain rate i.e. by $10 \%$ whereas compressive strength at strain rate of $5.0 \mathrm{~mm} / \mathrm{min}$ is $222 \mathrm{MPa}$ i.e. by $6 \%$. However, compressive strength observed at $50 \mathrm{~mm} / \mathrm{min}$ is 271.5 i.e. increased by $22 \%$. At $400{ }^{\circ} \mathrm{C}$, compressive strength at strain rate of $0.05 \mathrm{~mm} / \mathrm{min}$ is $153.1 \mathrm{MPa}$ which increased to $160 \mathrm{MPa}$ at $0.5 \mathrm{~mm} / \mathrm{min}$ i.e. by $4 \%$ and then increases to $174.6 \mathrm{MPa}$ at $5.0 \mathrm{~mm} / \mathrm{min}$ strain rate i.e. increases by $28 \%$. However, compressive strength observed at $50 \mathrm{~mm} / \mathrm{min}$ is 203.6 i.e. increased by $16 \%$. This postulates that with increase in strain rate the uniaxial compressive strength of the alkali granite increases.

It is further observed that Young's modulus value of alkali granite at room temperature and $0.05 \mathrm{~mm} / \mathrm{min}$ strain rate is $48.5 \mathrm{GPa}$ which increases to $57.4 \mathrm{GPa}$ at $0.5 \mathrm{~mm} / \mathrm{min}, 61.4 \mathrm{GPa}$ at $5.0 \mathrm{~mm} / \mathrm{min}$ and $90 \mathrm{GPa}$ at $50 \mathrm{~mm} / \mathrm{min}$ strain rates. Same trend was observed at 200 and $400{ }^{\circ} \mathrm{C}$ conditions. However, with a gradual increase in temperature, there is a reduction in Young's modulus value of the rock. At $0.5 \mathrm{~mm} / \mathrm{min}$, Young's modulus at room temperature is $48.5 \mathrm{GPa}$ which reduces to $42.8 \mathrm{GPa}$ at $200{ }^{\circ} \mathrm{C}$ and $32.8 \mathrm{GPa}$ at $400{ }^{\circ} \mathrm{C}$. Same trend was observed at other strain rate conditions.

\subsubsection{Bundelkhand granites: plagioclase granite}

A result of uniaxial compressive strength test at $0.5 \mathrm{~mm} / \mathrm{min}$ strain rate and at room temperature $\left(25^{\circ} \mathrm{C}\right)$ is shown in Fig. 19 which shows variation of axial strain and radial strain against stress. The failure of the specimen occurred in $5 \mathrm{~min}$. The peak load was $338 \mathrm{kN}$ and the compressive strength was
$225 \mathrm{MPa}$ with axial strain $0.03 \mathrm{~mm}$. From the Axial strain plot it was observed that after an initial adjustment between the loading plates and both ends of the sample, the plot is linear up to the failure load which signifies of an elastic zone. After the failure load the stress value suddenly drops to zero which indicates about an elastic-brittle failure with the absence of plastic zone.

Stress-strain curve of compressive strength test at room temperature $\left(25^{\circ} \mathrm{C}\right)$ and $0.05 \mathrm{~mm} / \mathrm{min}$ strain is shown in Fig. 20. The failure of the rock specimen occurred after $75 \mathrm{~min}$. The peak load was $361.8 \mathrm{kN}$ and the compressive strength was $227.4 \mathrm{MPa}$ with radial strain of 0.011 and axial strain 0.024 . The graph shows an elastic-brittle failure of the rock specimen at room temperature and $0.05 \mathrm{~mm} / \mathrm{min}$ strain rate.

Radial strain and Acoustic emission data plotted against compressive stress in Fig. 21. Based on the AE counts the time period is classified into crack closure, stable crack growth zone and unstable crack growth zone. It is observed that stable cracks forms between approximately 180 and $210 \mathrm{MPa}$ of stress and unstable crack growth occurs thereafter. Maximum number of AE hits recorded during the failure of the rock sample.

Result of Compressive strength test carried at room temperature $\left(25^{\circ} \mathrm{C}\right)$ and strain rate of $5.0 \mathrm{~mm} / \mathrm{min}$ is shown in Fig. 22. The failure of the rock specimen occurred in $<50 \mathrm{~s}$. The peak load was $529 \mathrm{kN}$ and the compressive strength was $338 \mathrm{MPa}$ with radial strain of 0.0017 and axial strain 0.037 . The axial strain plotted against compressive strength shows an elasticbrittle failure.

Similarly, the plot of AE data with strain against stress in Fig. 23 shows that stable crack growth developed between 50 and $230 \mathrm{MPa}$ of stress followed by unstable crack growth resulting in failure of the rock specimen.

Compressive strength test of the plagioclase granite was carried out at room temperature $\left(25^{\circ} \mathrm{C}\right)$ condition. Figure 24 shows the result of stress and $\mathrm{AE}$ counts against axial strain at room temperature. Failure of the specimen occurred in $4.26 \mathrm{~s}$. The peak load for the failure of the specimen was $502.7 \mathrm{kN}$ and the compressive strength was $321.2 \mathrm{MPa}$ with an axial strain of 0.036 . Based on the AE counts in the graph it is observed that formation of stable cracks starts from approximately $70 \mathrm{MPa}$ of stress and continues to $220 \mathrm{MPa}$ of stress. Thereafter, unstable crack growth occurred until the failure of the rock specimen. 
Fig. 19 Graph showing trend of axial strain and radial strain plotted against stress tested at room temperature $\left(25^{\circ} \mathrm{C}\right)$ and $0.5 \mathrm{~mm} / \mathrm{min}$ strain rate
Fig. 20 Graph showing trend of axial strain and radial strain plotted against stress tested at room temperature $\left(25{ }^{\circ} \mathrm{C}\right)$ and $0.05 \mathrm{~mm} / \mathrm{min}$ strain rate
Fig. 21 Graph showing plot of the radial strain and the acoustic emission counts against the stress for the compressive strength test at room temperature $\left(25^{\circ} \mathrm{C}\right)$ and $0.5 \mathrm{~mm} / \mathrm{min}$ strain rate
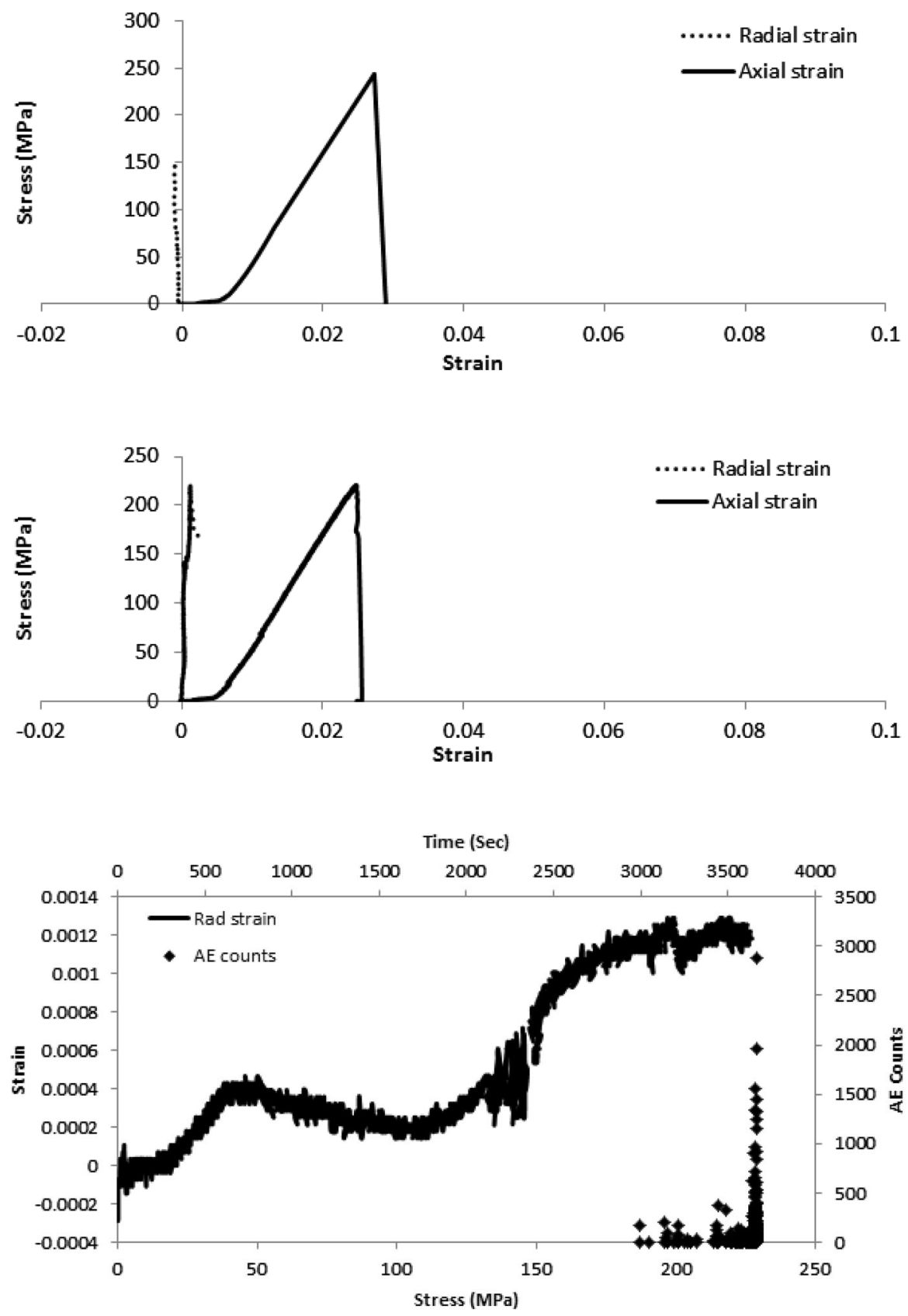

In Fig. 25, graph shows-stress strain curve of the specimen for $200{ }^{\circ} \mathrm{C}$ test at $0.5 \mathrm{~mm} / \mathrm{min}$ strain rate. Failure of the rock specimen occurred within $7 \mathrm{~min}$. The peak load was $332 \mathrm{kN}$ and the compressive strength was $220 \mathrm{MPa}$ with radial strain of 0.00067 and axial strain 0.036. It is observed that even at $200{ }^{\circ} \mathrm{C}$ there was no plastic deformation occurred indicating an elastic-brittle failure of the specimen.
The stress strain curve of the compressive strength test at $400{ }^{\circ} \mathrm{C}$ and 0.5 strain rate is shown in Fig. 26. Failure of the rock specimen occurred within 6 min of the experiment. The peak load was $227 \mathrm{kN}$ and the compressive strength was $146 \mathrm{MPa}$ with radial strain of 0.007 and axial strain 0.033 . It is observed that even at $400{ }^{\circ} \mathrm{C}$ there is no plastic deformation occurred indicating an elastic-brittle failure of the specimen. 
Fig. 22 Graph showing trend of axial strain and radial strain plotted against stress tested at room temperature $\left(25{ }^{\circ} \mathrm{C}\right)$ and $5.0 \mathrm{~mm} / \mathrm{min}$ strain rate

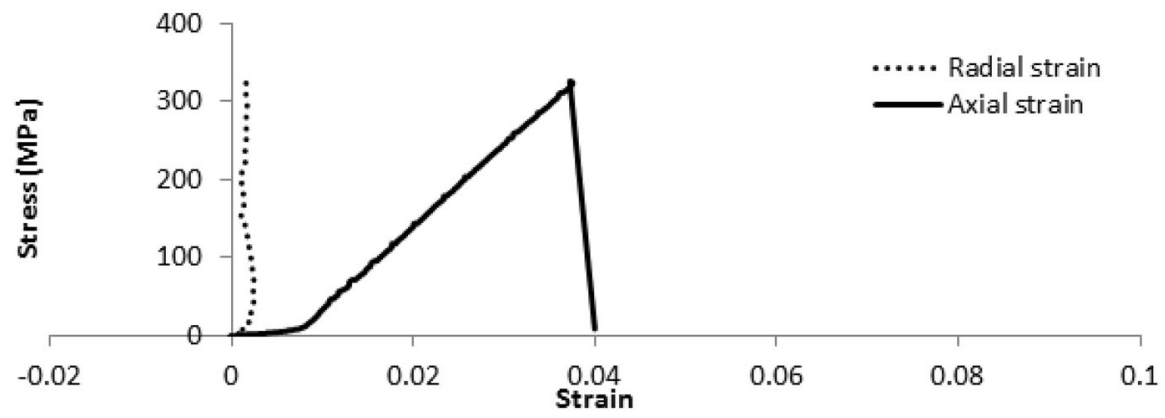

Fig. 23 Graph showing plot of the radial strain and the acoustic emission counts against the stress for the compressive strength test at room temperature $\left(25^{\circ} \mathrm{C}\right)$ and $5.0 \mathrm{~mm} / \mathrm{min}$ strain rate

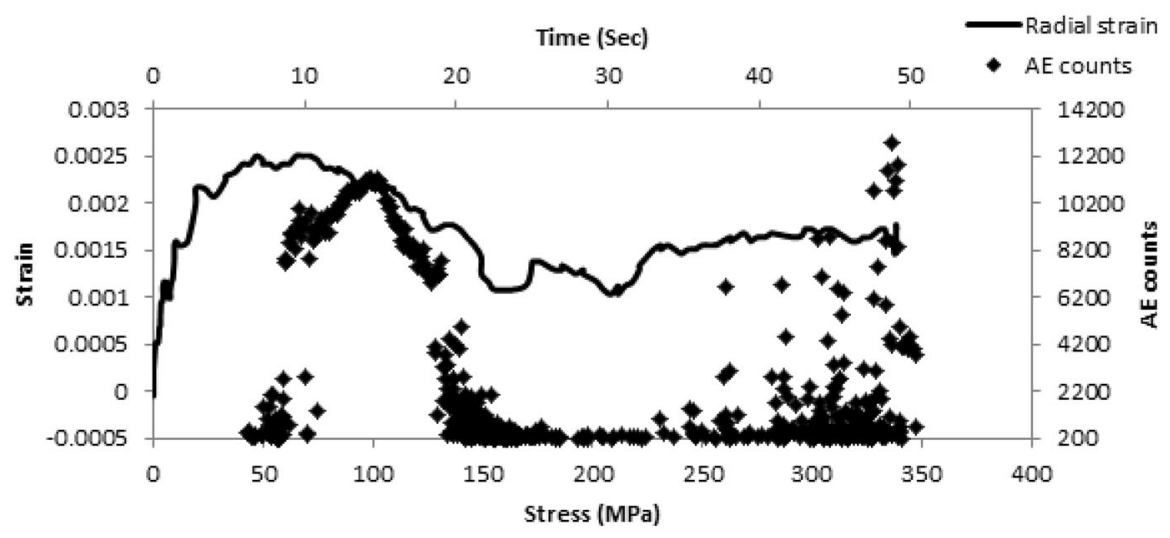

Fig. 24 Graph showing plot of stress and AE counts against axial strain at room temperature $\left(25^{\circ} \mathrm{C}\right)$ and $50.0 \mathrm{~mm} / \mathrm{min}$ strain rate

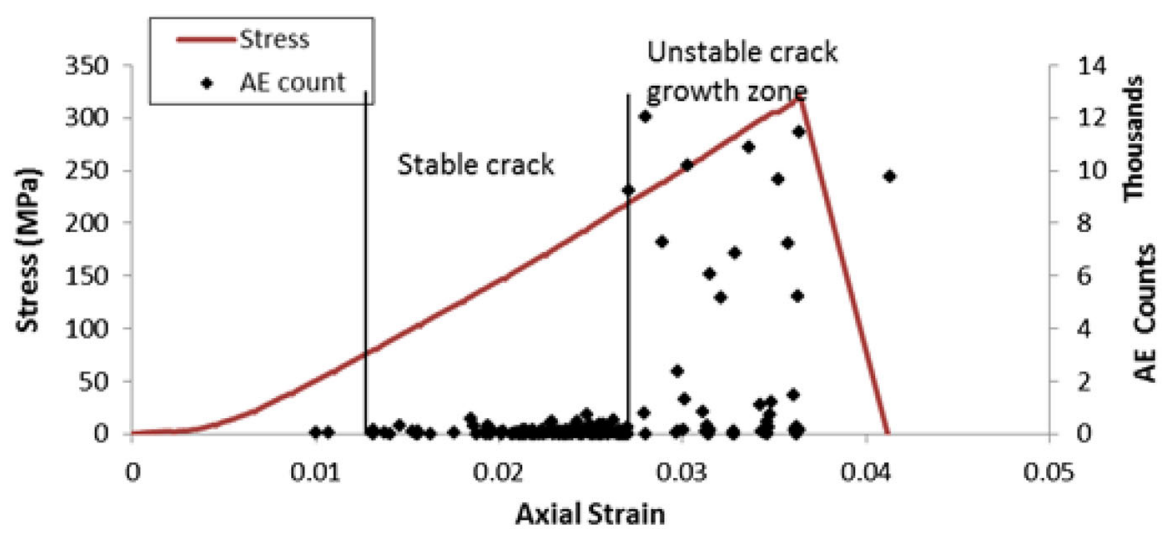

Acoustic emission data indicates that stable crack growth occurred after $40 \mathrm{MPa}$ stress followed by unstable crack growth after $95 \mathrm{MPa}$ stress (Fig. 27).

From the stress-strain curves for different temperature and strain rate it is observed that at specific temperature the axial strain at failure increases with increase in strain rate. Similarly, at specific strain rate the axial strain at failure increases from room temperature $\left(25{ }^{\circ} \mathrm{C}\right)$ to $200{ }^{\circ} \mathrm{C}$ while it reduces at higher temperature condition.

Compressive strength of plagioclase granite of Bundelkhand granites at various temperature and strain rate condition are listed below in Table 2 and plotted in Figs. 28 and 29.

From the experimental analysis (Table 2; Fig. 28) it is observed that at strain rate of $0.05 \mathrm{~mm} / \mathrm{min}$, the 
Fig. 25 Graph showing trend of axial strain and radial strain plotted against stress tested at $200{ }^{\circ} \mathrm{C}$ and $0.5 \mathrm{~mm} / \mathrm{min}$ strain rate

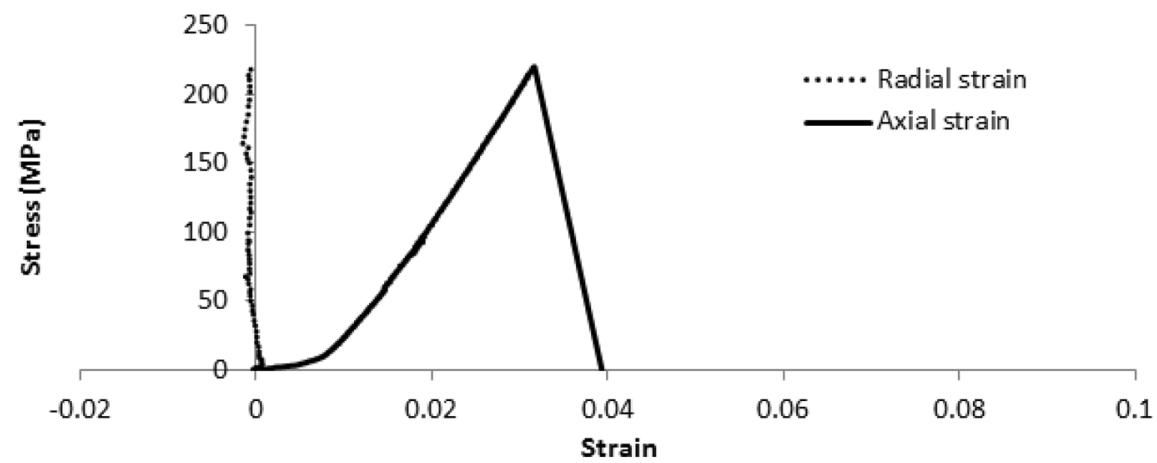

Fig. 26 Graph showing trend of axial strain and radial strain plotted against stress tested at $400{ }^{\circ} \mathrm{C}$ and $0.5 \mathrm{~mm} / \mathrm{min}$ strain rate

Fig. 27 Graph showing plot of the radial strain and the acoustic emission counts against the stress for the compressive strength test at $400{ }^{\circ} \mathrm{C}$ and $0.5 \mathrm{~mm} / \mathrm{min}$ strain rate
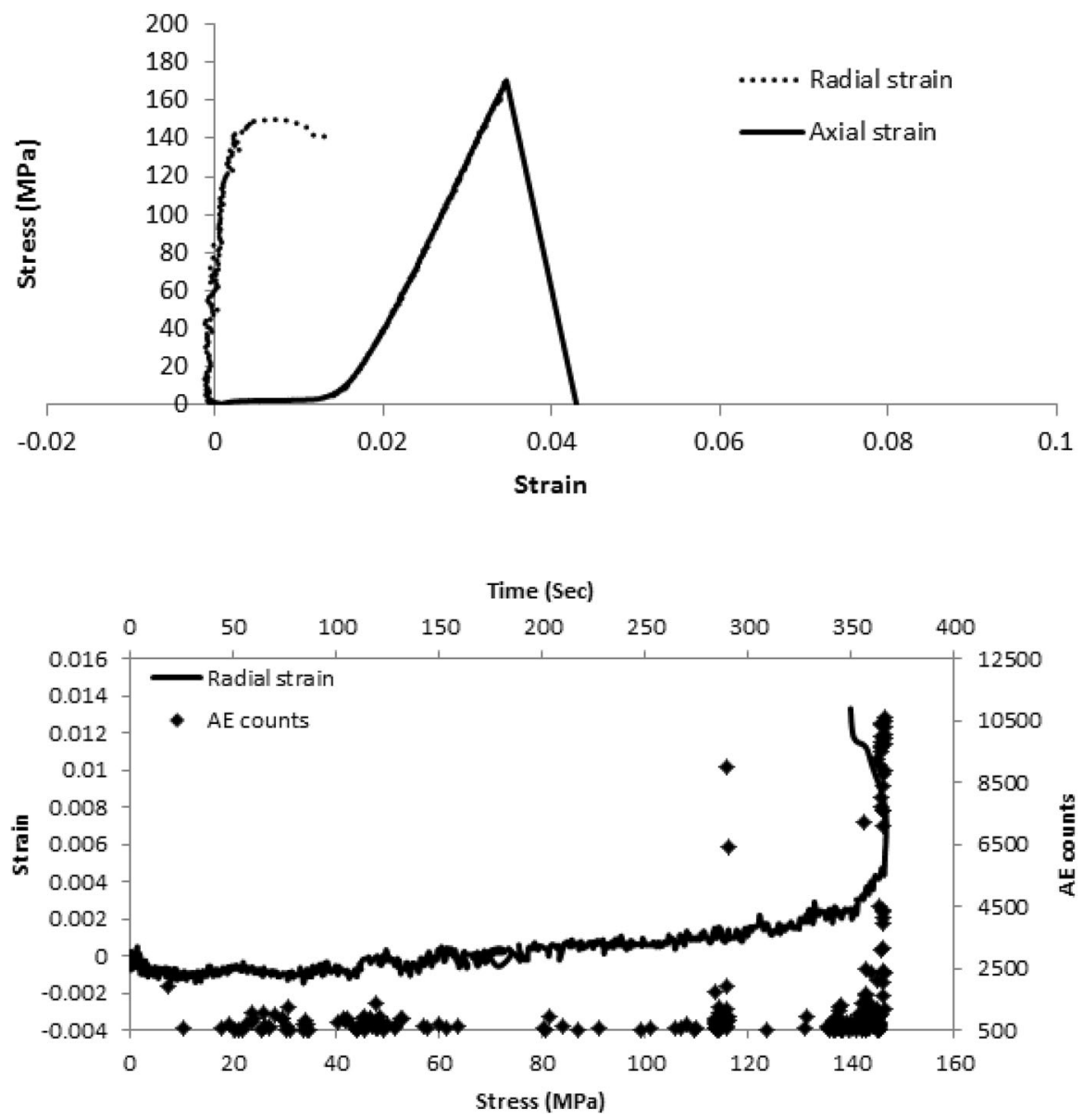

compressive strength at room temperature $\left(25^{\circ} \mathrm{C}\right)$ is 220.9 MPa which increased to $215.9 \mathrm{MPa}$ at $200{ }^{\circ} \mathrm{C}$ i.e. by $2 \%$, and further decreased to $157.5 \mathrm{MPa}$ at $400{ }^{\circ} \mathrm{C}$ i.e. by $27 \%$. At strain rate of $0.5 \mathrm{~mm} / \mathrm{min}$, the compressive strength at room temperature is $225 \mathrm{MPa}$ which decreased to $220 \mathrm{MPa}$ at $200{ }^{\circ} \mathrm{C}$ i.e. by $2 \%$, and further decreased to $160.1 \mathrm{MPa}$ at $400{ }^{\circ} \mathrm{C}$ i.e. by $27 \%$. At strain rate of $5.0 \mathrm{~mm} / \mathrm{min}$, the compressive strength of the rock at room temperature is $325.9 \mathrm{MPa}$ which decreased to $254 \mathrm{MPa}$ at $200{ }^{\circ} \mathrm{C}$ i.e. by $22 \%$ and further decreased to $161.7 \mathrm{MPa}$ i.e. by $36 \%$. At strain rate of $50.0 \mathrm{~mm} / \mathrm{min}$, the compressive strength 
Table 2 Thermo mechanical properties of plagioclase granite of Bundelkhand granite at different temperature and strain rate conditions

\begin{tabular}{|c|c|c|c|c|c|c|c|c|c|}
\hline \multirow{3}{*}{$\begin{array}{l}\text { Strain rate } \\
(\mathrm{mm} / \mathrm{min})\end{array}$} & \multicolumn{9}{|c|}{ Temperature } \\
\hline & \multicolumn{3}{|l|}{$25^{\circ} \mathrm{C}$} & \multicolumn{3}{|l|}{$200{ }^{\circ} \mathrm{C}$} & \multicolumn{3}{|l|}{$400{ }^{\circ} \mathrm{C}$} \\
\hline & $\begin{array}{l}\mathrm{UCS} \\
(\mathrm{MPa})\end{array}$ & $\begin{array}{l}\text { Axial } \\
\text { strain }\end{array}$ & $\begin{array}{l}\text { Y's modulus } \\
\text { (Gpa) }\end{array}$ & $\begin{array}{l}\mathrm{UCS} \\
(\mathrm{MPa})\end{array}$ & $\begin{array}{l}\text { Axial } \\
\text { strain }\end{array}$ & $\begin{array}{l}\text { Y's modulus } \\
\text { (Gpa) }\end{array}$ & $\begin{array}{l}\mathrm{UCS} \\
(\mathrm{MPa})\end{array}$ & $\begin{array}{l}\text { Axial } \\
\text { strain }\end{array}$ & $\begin{array}{l}\text { Y's modulus } \\
\text { (Gpa) }\end{array}$ \\
\hline 0.05 & 220.9 & 0.0043 & 51.7 & 215.9 & 0.0043 & 49.8 & 157.5 & 0.0046 & 34.1 \\
\hline 0.5 & 225 & 0.0040 & 55.8 & 220 & 0.0040 & 55.0 & 160.1 & 0.0044 & 36.1 \\
\hline 5.0 & 325.9 & 0.0039 & 83.0 & 254 & 0.0039 & 65.0 & 161.7 & 0.0041 & 39.2 \\
\hline 50.0 & 321.2 & 0.0037 & 87.0 & 262.9 & 0.0038 & 70.0 & 178.4 & 0.0039 & 46.0 \\
\hline
\end{tabular}

Fig. 28 Average compressive strength of alkali granites for different strain rates at different temperature

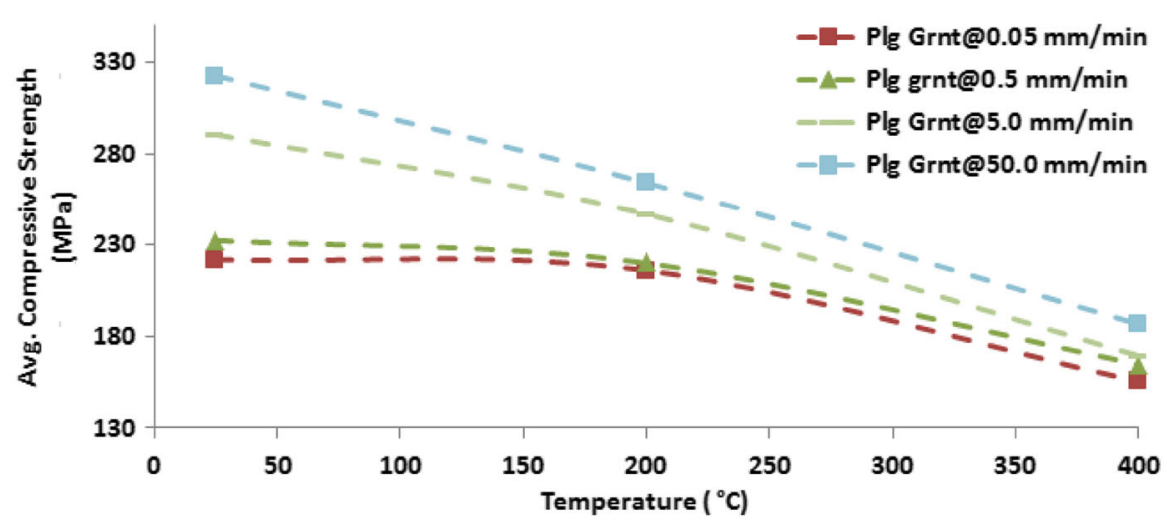

Fig. 29 Average compressive strength of alkali granites for different temperature at different strain rate

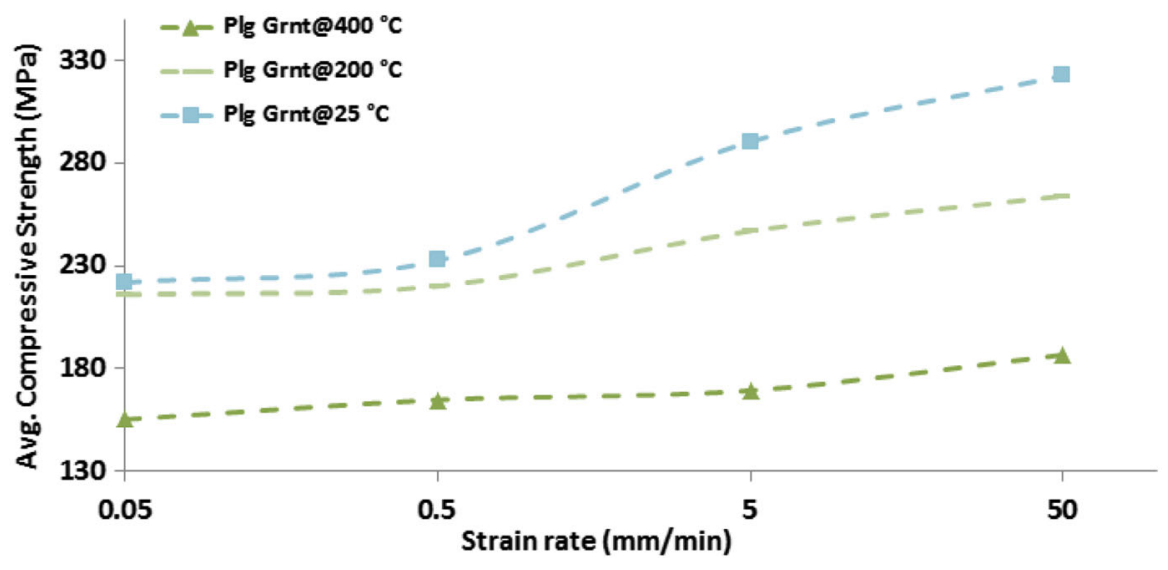

Similarly from Table 2 and Fig. 29 it is observed that at room temperature $\left(25^{\circ} \mathrm{C}\right)$ and $0.05 \mathrm{~mm} / \mathrm{min}$ the compressive strength of the value is $220.9 \mathrm{MPa}$ which increases to $225 \mathrm{MPa}$ at $0.5 \mathrm{~mm} / \mathrm{min}$ i.e. by $2 \%$ and further increases to $338.4 \mathrm{MPa}$ at $5.0 \mathrm{~mm} / \mathrm{min}$ i.e. increases by $45 \%$. However, compressive strength at $50.0 \mathrm{~mm} / \mathrm{min}$ strain rate is $321.2 \mathrm{MPa}$ i.e. insignificant 
Fig. 30 Acoustic emission versus laser extension data of the specimen at a $200{ }^{\circ} \mathrm{C}$ test, b $400{ }^{\circ} \mathrm{C}$ test
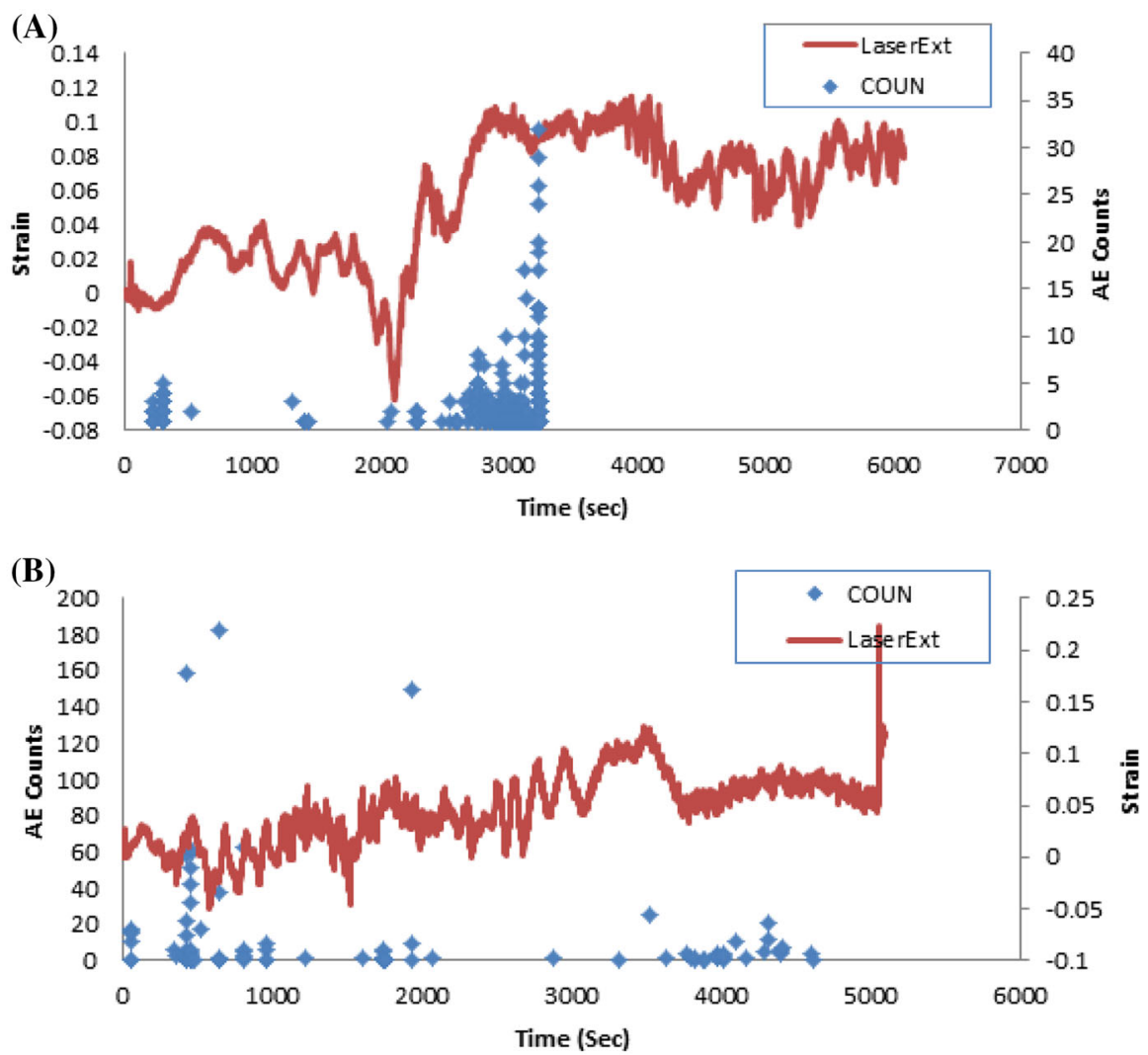

change observed. At $200{ }^{\circ} \mathrm{C}$ temperature, the compressive strength at $0.05 \mathrm{~mm} / \mathrm{min}$ strain rate is $215.9 \mathrm{MPa}$ which increased to $220 \mathrm{MPa}$ at $0.5 \mathrm{~mm} / \mathrm{min}$ strain rate i.e. by $2 \%$ which further increased to $254.0 \mathrm{MPa}$ at strain rate of $5.0 \mathrm{~mm} / \mathrm{min}$ i.e. increased by $15 \%$. However, compressive strength at $50.0 \mathrm{~mm} / \mathrm{min}$ strain rate is $263 \mathrm{MPa}$ i.e. increased by $3 \%$. At $400{ }^{\circ} \mathrm{C}$ temperature, compressive strength at strain rate of $0.05 \mathrm{~mm} / \mathrm{min}$ is $157.5 \mathrm{MPa}$ which increased to $160.1 \mathrm{MPa}$ at $0.5 \mathrm{~mm} / \mathrm{min}$ i.e. by $2 \%$ and further increased to $161.7 \mathrm{MPa}$ at $5.0 \mathrm{~mm} / \mathrm{min}$ strain rate i.e. by $1 \%$. However, compressive strength at $50.0 \mathrm{~mm} / \mathrm{min}$ strain rate is $178.4 \mathrm{MPa}$ i.e. increased by $10 \%$. This postulates that increase in strain rate the uniaxial compressive strength of the rock increases.

It is further observed that Young's modulus value of plagioclase rock at room temperature and $0.05 \mathrm{~mm} / \mathrm{min}$ strain rate is $51.7 \mathrm{GPa}$ which increases to $55.8 \mathrm{GPa}$ at $0.5 \mathrm{~mm} / \mathrm{min}, 83 \mathrm{GPa}$ at $5.0 \mathrm{~mm} / \mathrm{min}$ and $87 \mathrm{GPa}$ at $50 \mathrm{~mm} / \mathrm{min}$ strain rates. Same trend was observed at 200 and $400{ }^{\circ} \mathrm{C}$ conditions. However, with a gradual increase in temperature, there is a reduction in Young's modulus value of the rock. At $0.5 \mathrm{~mm} / \mathrm{min}$, Young's modulus at room temperature is $51.7 \mathrm{GPa}$ which reduces to $49.8 \mathrm{GPa}$ at $200{ }^{\circ} \mathrm{C}$ and $34.1 \mathrm{GPa}$ at $400{ }^{\circ} \mathrm{C}$. Same trend was observed at other strain rate conditions.

Laser extensometer and acoustic emission data collected during the heating process of the specimen up to 200 and $400{ }^{\circ} \mathrm{C}$ temperatures were analyzed to study the thermal expansion of the specimen (Fig. 30a, b).

From the results it was found that for any disturbance due to sudden release of energy within the specimen during the heating process generates a response in Acoustic emission record which coincides with the fluctuation in the laser extension record. The sharp fluctuation or spike in $\mathrm{AE}$ record can be considered a result of thermal expansion due to stress accumulation eventually resulting in the formation of a thermal crack. This suggests that each event within the specimen which indicates the growth of thermal cracks is marked by a sharp fluctuation or spike within the Laser extensometer data. 
Fig. 31 Average thermal conductivity of the Bundelkhand granites
Thermal conductivity

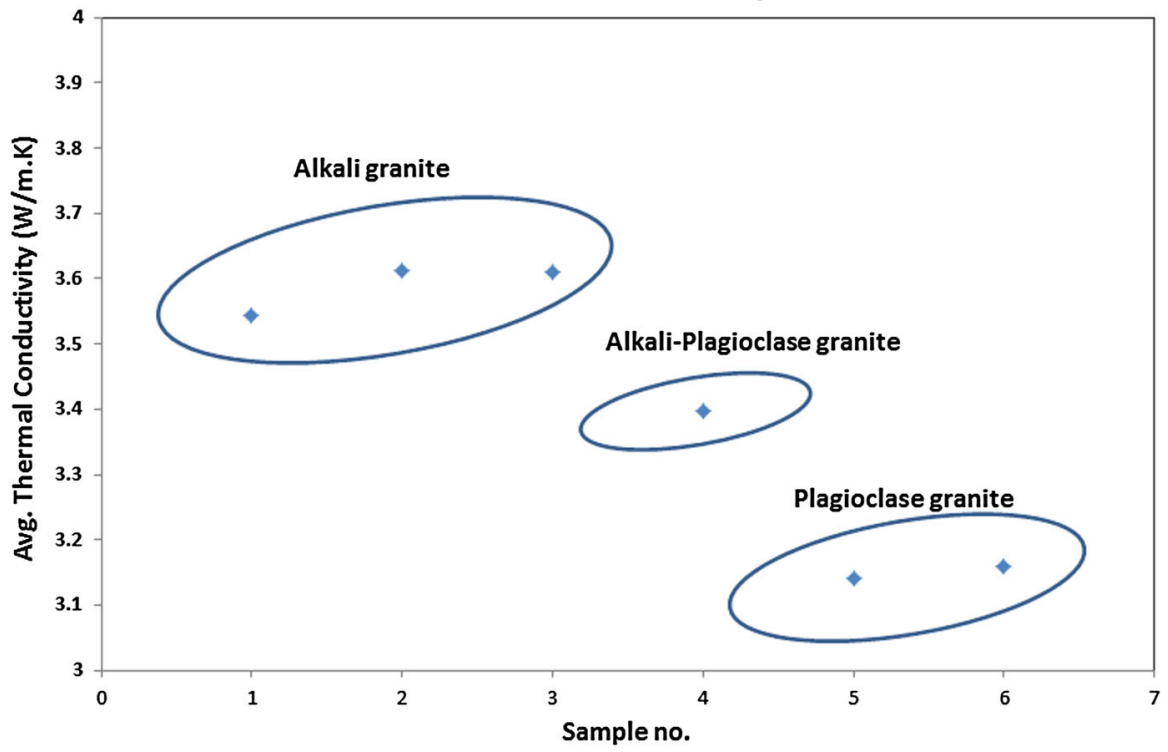

\section{Thermal conductivity}

Thermal conductivity of the Bundelkhand granites are measured by using the Divided bar method. Thermal conductivity of alkali granite varies from 3.5 to $3.6 \mathrm{~W} / \mathrm{m} \mathrm{K}$ whereas thermal conductivity of plagioclase granite is measured as $3.15 \mathrm{~W} / \mathrm{m} \mathrm{K}$. Alkali granite in which plagioclase content is relatively higher has thermal conductivity value of $3.4 \mathrm{~W} / \mathrm{m} \mathrm{K}$ (Fig. 31).

\section{Conclusions}

From the petrographic study, Bundelkhand granites can be characterized as alkali granites and plagioclase granite. The mechanical properties investigation at room temperature explicates behavior of Bundelkhand granite under different strain rates. Due to chipping effect towards the end of each test the strain measurement gets interrupted. The acoustic emission count helps to easily delineate the stable crack growth zone and unstable crack growth zone.

It was observed that the strength of the rock varies with different strain rates. The UCS test on the alkali granite and the plagioclase granite seems to follow the observation that has been observed by the earlier workers i.e. with the increase in temperature the compressive strength of the rock decreased. Though the decrease in uniaxial compressive strength is not significant from room temperature $\left(30{ }^{\circ} \mathrm{C}\right)$ to $200{ }^{\circ} \mathrm{C}$, but further increase in temperature (at $400{ }^{\circ} \mathrm{C}$ ) has shown a significant amount of decrease in the compressive strength of the Bundelkhand granite. This phenomenon may be a result of growth of thermal micro-cracks due the heating process of the specimen.

The effect of strain rate on the uniaxial compressive strength has also been demonstrated from the result. Both alkali granites and plagioclase granite show the trend of increase in uniaxial compressive strength value with increase in strain rate. But in plagioclase granites, increase in compressive strength is insignificant from low strain rate $(0.05 \mathrm{~mm} / \mathrm{min})$ to standard strain rate $(0.5 \mathrm{~mm} / \mathrm{min})$. But at higher strain rate $(5.0 \mathrm{~mm} / \mathrm{min})$ to very high strain rate $(50.0 \mathrm{~mm} / \mathrm{min})$ it increases significantly with a very wide range of distribution from room temperature to $400{ }^{\circ} \mathrm{C}$ which is probably due to the formation of micro-cracks at higher temperature.

It is also observed that there is a gradual increase in young's modulus of rock as the rock subjected to higher strain rate conditions. Whereas increasing temperature leads to decline in Young's modulus for a particular strain rate condition.

Thermal conductivity of the alkali granite is $3.55 \mathrm{~W} / \mathrm{m} \mathrm{K}$ whereas thermal conductivity of the plagioclase granite is $3.15 \mathrm{~W} / \mathrm{m} \mathrm{K}$. 


\section{References}

Basu AK (1986) Geology of Bundelkhand granite massif, Central India. Geol Surv India Rec 101:61-124

Chandrasekharam D, Chandrasekhar V (2008) Granites and granites: India's warehouse of EGS. Bull. Geotherm Res Counc 37:17-20

Chandrasekharam D, Chandrasekhar V (2010) Hot dry rock potential in India: Future road map to make India energy Independent. In: World Geothermal Congress 2010. Bali

Dwivedi R, Goel R, Prasad V, Sinha A (2008) Thermo-mechanical properties of Indian and other granites. Int J Rock Mech Min Sci 45:303-315

Heuze FE (1983) High-temperature mechanical, physical and Thermal properties of granitic rocks: a review. Int J Rock Mech Min Sci Geomech Abstr 20(1):3-10

Hudson JA, Stephansson O, Andersson J (2005) Guidance on numerical modeling of thermo-hydro-mechanical coupled processes for performance assessment of radioactive waste repositories. Int J Rock Mech Min Sci 42(5/6):850-870

Katz O, Reches Z, Roegiers JC (2000) Evaluation of mechanical rock properties using a Schmidt Hammer. Int J Rock Mech Min Sci 37(4):723-728

Malviya VP, Arima M, Pati JK, Kaneko Y (2006) Petrology and geochemistry of metamorphosed basaltic pillow lava and basaltic komatiite in Mauranipur area: subduction related volcanism in Archean Bundelkhand craton, Central India. J Mineral Petrol Sci 101:199-217

Minissale A, Vaselli O, Chandrasekharam D, Magro G, Tassi F, Casiglia A (2000) Origin and evolution of "intracratonic" thermal fluids from central western peninsular India. Earth Planet Sci Lett 181:377-394

Mondal MEA, Goswami JN, Deomurari MP, Sharma KK (2002) Ion microprobe $207 \mathrm{~Pb} / 206 \mathrm{~Pb}$ ages of zircons from the Bundelkhand massif, northern India: implications for crustal evolution of the Bundelkhand-Aravalli protocontinent. Precambrian Res 117:85-100

Pati JK, Raju S, Pruseth KL, Malviya VP, Arima M, Pati P, Prakash K (2007) Geology and geochemistry of giant quartz veins from the Bundelkahand craton, Central India and its implications. J Earth Syst Sci 116:497-510
Ranjith PG, Jasinge D, Song JY, Choi SK (2008) A study of the effect of strain rate and moisture content on mechanical properties of concrete: Use of acoustic emission. Mech Mater 40, 453-469

Sarkar SN, Ghosh DK, Lambert RJS (1985) Rubidium-strontium lead isotopic studies of the soda granites from Mosabani, Singhbhum Copper Belt, India. Indian J Earth Sci 13:101-116

Singh B, Ranjith PG, Chandrasekharam D, Viete D, Singh HK (2013) Thermo-mechanical properties of Harcourt granite, Australia. International Conference on Applied Energy 2013, 1-4 July 2013, Pretoria, South Africa. Proceeding paper ID-ICAE-414, 1-9

Singh B, Ranjith PG, Singh HK, Chandrasekharam D (2015) Possible Enhanced Geothermal System potentia 91 of high heat producing radioactive Bundelkhand granite. In: Proceedings world geothermal congress 2015, Melbourne (to be held from 19-25 April 2015)

Vasconcelos G, Lourec OPB, Alves CSA, Pamplona J (2007) Prediction of the mechanical properties of granites by ultrasonic pulse velocity and Schmidt hammer hardness, North American Masonry Conference, June 3-6. St Louis, Missouri, pp 980-991

Wasantha PLP, Ranjith PG, Shao SS (2013) Energy monitoring and analysis during deformation of bedded-sandstone: Use of acoustic emission. Ultrason J 54(1):217-226

Xu XC, Liu QS (2000) A preliminary study on basic mechanical properties for granite at high temperature (in Chinese). Chin J Geotech Eng 22(3):332-335

Zhang LY, Mao XB, Lu AH (2009) Experimental study on the mechanical properties of rocks at high temperature. Sci China Ser E Technol Sci 52(3):641-646

Zhao J (1994) Geothermal testing and measurements of rock and rock fractures. Int J Geotherm Res Appl 23:215-231

Zuo JP (2006) Sandstone failure mechanism at the meso-scale and its strength characteristics under the thermal-mechanical action (in Chinese). Doctoral Dissertation. Beijing, University of Mining and Technology (Beijing) 